DOE/WIPP 02-3220

Revision 1, December 2002

\title{
CH Packaging Operations for High Wattage Waste at LANL
}

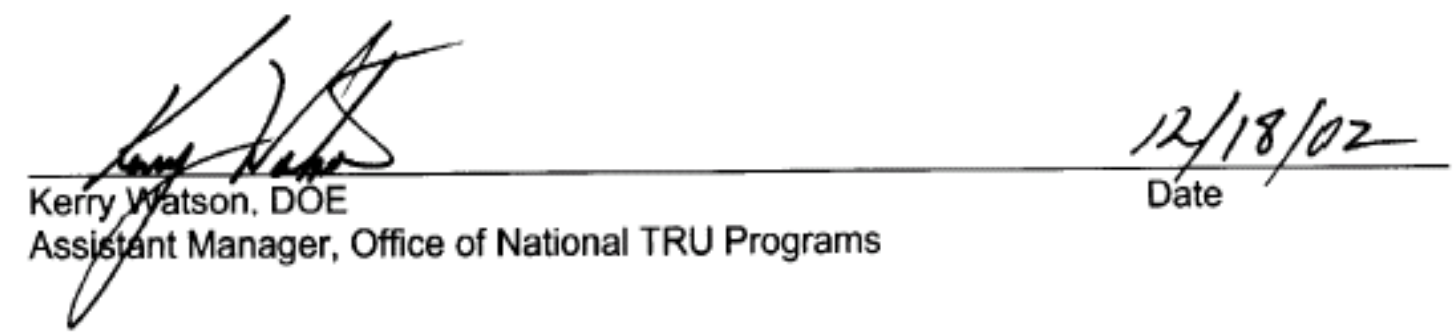

Processing and final preparation of this paper was performed by Westinghouse TRU Solutions, LLC, the WIPP management and operating (M\&O) contractor for the Waste Isolation Pilot Plant under

US Department of Energy contract number DE-AC04-01AL66444. This document has been submitted as required to:

\author{
Office of Scientific and Technical Information \\ P.O. Box 62 \\ Oak Ridge, TN 37831 \\ (615) $576-8401$
}

Additional Information about this document may be obtained by calling (800) 336-9477. Copies may be obtained by contacting the National Technical Information Service, US Department of Commerce, 5285 Port Royal Road, Springfield, VA 22101. 


\section{RECORD OF REVISION}

Revision Reason for Revision/Change

$0 \quad$ New $\mathrm{CH}$ Packaging Operations Manual for shipping LANL high wattage waste. This document must be used in conjunction with DOE/WIPP 02-3183, CH Packaging Program Guidance, and DOE/WIPP 02-3185, CH Packaging Maintenance Manual.

$1 \quad$ Changes in Sections 2.17, 2.18, and 2.20, and Figure 2.1, to address results of validation process at LANL. This document must be used in conjunction with DOE/WIPP 02-3183, CH Packaging Program Guidance, and DOE/WIPP 02-3185, $\mathrm{CH}$ Packaging Maintenance Manual. 


\begin{tabular}{|c||}
\hline M\&O CONTRACTOR TECHNICAL REVIEW ORGANIZATIONS \\
\hline WESTINGHOUSE TRU SOLUTIONS \\
\hline CBFO REVIEW ORGANIZATIONS \\
NATIONAL TRU PROGRAMS \\
QUALITY ASSURANCE \\
EDITORIAL \\
\hline
\end{tabular}




\section{TABLE OF CONTENTS}

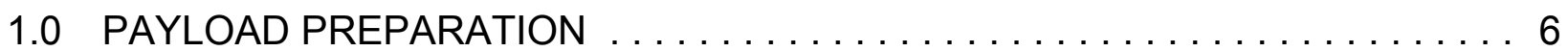

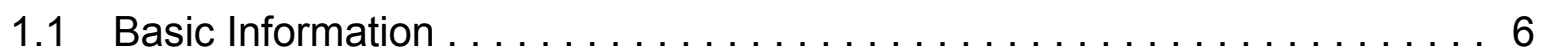

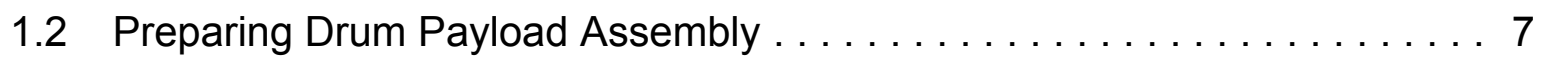

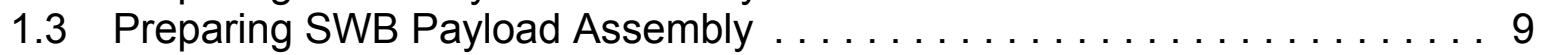

1.4 Preparing TDOP Payload Assembly $\ldots \ldots \ldots \ldots \ldots \ldots \ldots \ldots \ldots$

2.0 NORMAL OPERATING INSTRUCTIONS . . . . . . . . . . . . . . . . . 14

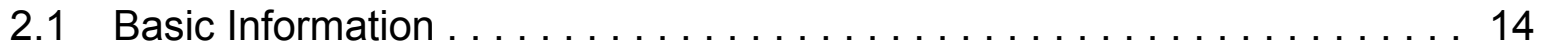

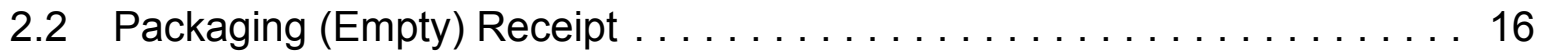

2.3 Releasing Tie-downs and Removal of Packaging from Trailer . . . . . 17

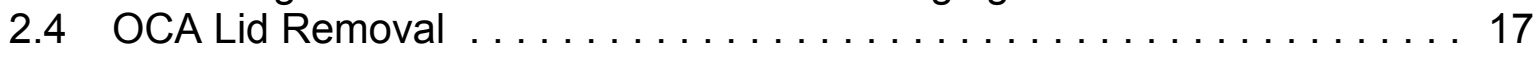

2.5 ICV Lid Removal . . . . . . . . . . . . . . . . . . . 19

2.6 Preloading/Shipping Operational Checks and Examinations . . . . . . . 20

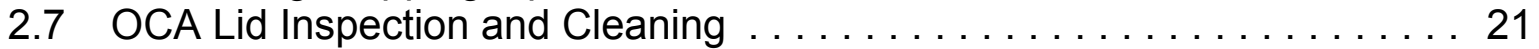

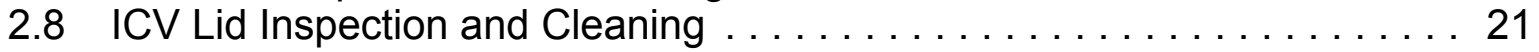

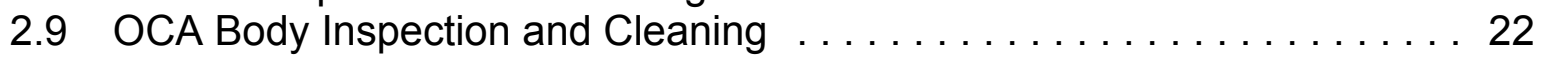

2.10 OCA Components Inspection and Cleaning $\ldots \ldots \ldots \ldots \ldots \ldots \ldots 23$

2.11 ICV Body Inspection and Cleaning ..................... 24

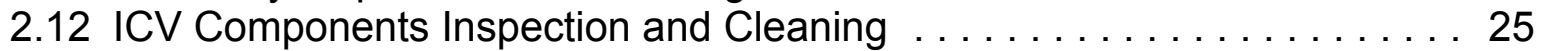

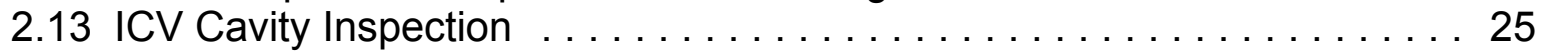

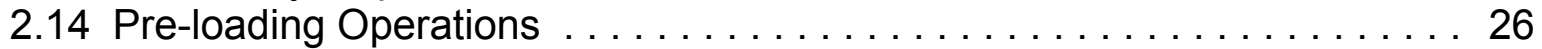

2.15 Packaging Receipt and Inspection Data Sheet Validation . . . . . . . 26

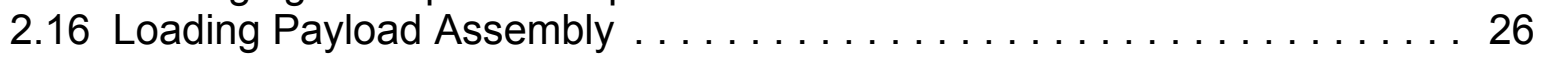

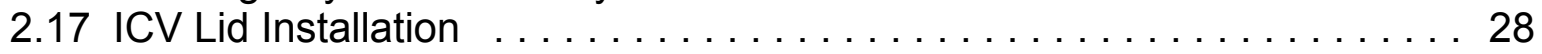

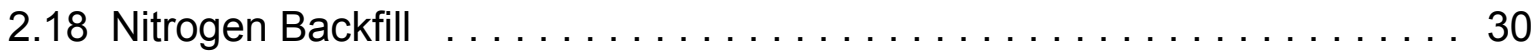

2.19 OCA Lid Installation . . . . . . . . . . . . . . . . . 32

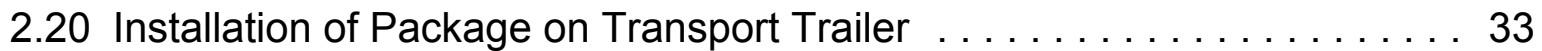

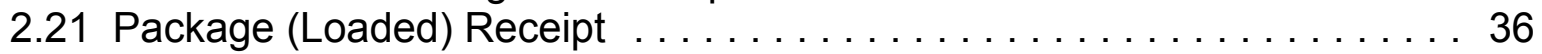

2.22 Releasing Tie-downs and Removal of Package from Trailer . . . . . . . 37

2.23 OCA Lid Removal . . . . . . . . . . . . . . . . . . . 38

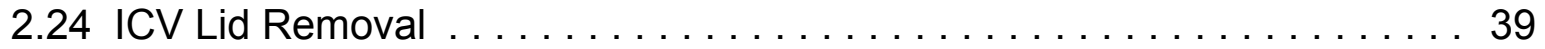

2.25 Unloading Payload Assembly $\ldots \ldots \ldots \ldots \ldots \ldots \ldots \ldots \ldots \ldots \ldots 41$

2.26 Packaging Operational Checks and Examinations $\ldots \ldots \ldots \ldots \ldots 42$

2.27 OCA Lid Inspection and Cleaning . . . . . . . . . . . . . . 43

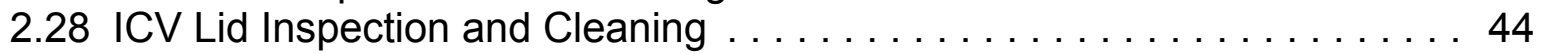

2.29 OCA Body Inspection and Cleaning . . . . . . . . . . . . . 44

2.30 OCA Components Inspection and Cleaning .............. 45

2.31 ICV Body Inspection and Cleaning ..................... 46

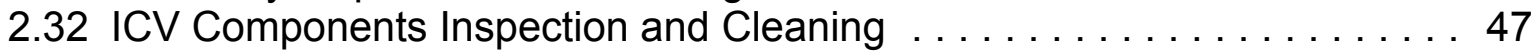

2.33 ICV Cavity Inspection $\ldots \ldots \ldots \ldots \ldots \ldots \ldots \ldots \ldots \ldots \ldots \ldots \ldots \ldots$

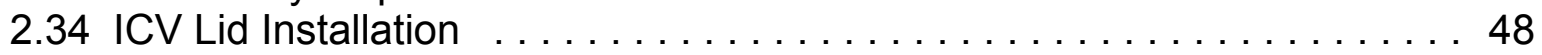

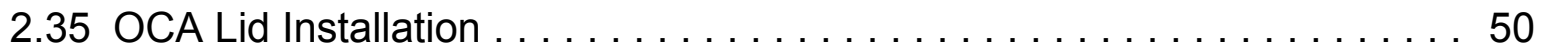

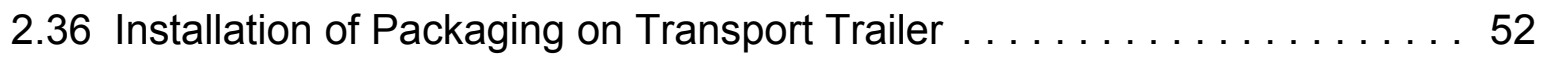

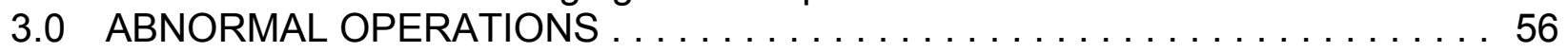

3.1 Empty ICV Assembly Removal $\ldots \ldots \ldots \ldots \ldots \ldots \ldots \ldots \ldots \ldots$

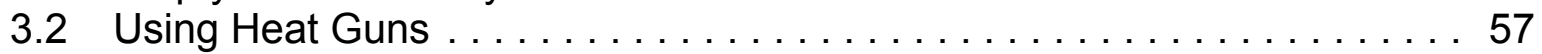

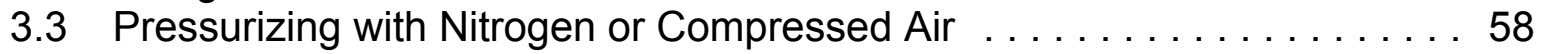

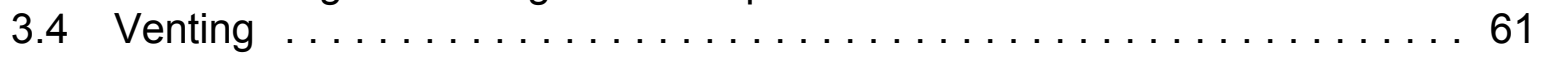


4.0 PRESHIPMENT LEAKAGE RATE TESTING $\ldots \ldots \ldots \ldots \ldots \ldots \ldots \ldots \ldots \ldots$

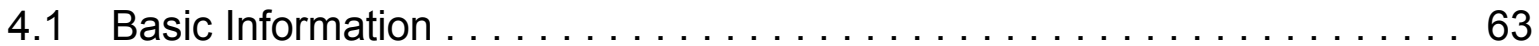

4.2 ICV Upper Main O-Ring Seal $\ldots \ldots \ldots \ldots \ldots \ldots \ldots \ldots \ldots \ldots 6$

4.3 ICV Outer Vent Port Plug O-Ring Seal $\ldots \ldots \ldots \ldots \ldots \ldots \ldots \ldots$

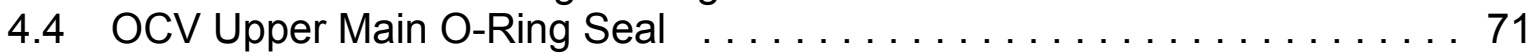

4.5 OCV Vent Port Plug O-Ring Seal $\ldots \ldots \ldots \ldots \ldots \ldots \ldots \ldots \ldots \ldots$

Attachment 1 - LANL High Wattage CH Packaging Receipt and Inspection Data

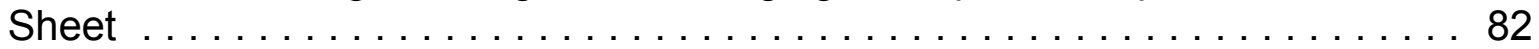

Attachment 2 - LANL High Wattage CH Packaging Loading Data Sheet ......... 83

Attachment 3 - LANL High Wattage Loaded CH Package Trailer Data Sheet . . . . 84

Attachment 4 - LANL High Wattage Loaded Package Receipt and Processing Data

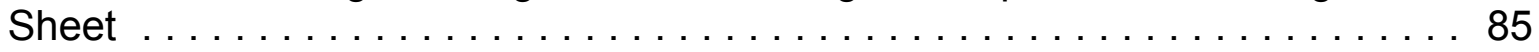

Attachment 5 - LANL High Wattage Empty Packaging Shipment Data Sheet $\ldots . .86$

Attachment 6 - LANL High Wattage Trailer Data Sheet $\ldots \ldots \ldots \ldots$

Attachment 7 - ICV Preshipment Leakage-Rate Test Data Sheet $\ldots \ldots \ldots \ldots \ldots 89$

Attachment 8 - OCV Preshipment Leakage-Rate Test Data Sheet $\ldots \ldots \ldots \ldots 92$

Attachment 9 - Time and Date Data Sheet for Shipment of Content Code LA 154 .. 95

Attachment 10 - Time and Date Data Sheet for Receipt of Content Code LA-154 . . 96

\section{LIST OF FIGURES}

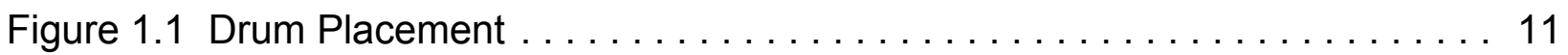

Figure 1.2 Drum Payload Assembly, Typical . . . . . . . . . . . . . . 12

Figure 1.3 SWB Adjustable Lifting Slings $\ldots \ldots \ldots \ldots \ldots \ldots \ldots \ldots \ldots \ldots \ldots \ldots$

Figure 2.1. Evacuation/Nitrogen Backfill $\ldots \ldots \ldots \ldots \ldots \ldots \ldots \ldots \ldots \ldots$

Figure 3.1 Flow Diagram for Nitrogen Bottle/Compressed Air ICV/OCA Lid

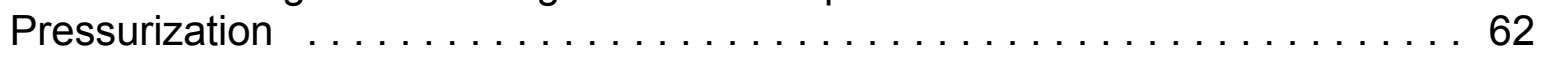

Figure 4.1 ICV Main O-ring Seal Test $\ldots \ldots \ldots \ldots \ldots \ldots \ldots \ldots \ldots \ldots$

Figure 4.2 ICV Outer Vent Port Plug O-ring Seal Test . . . . . . . . . . 79

Figure 4.3 OCV Main O-ring Seal Test $\ldots \ldots \ldots \ldots \ldots \ldots \ldots \ldots \ldots \ldots \ldots \ldots \ldots$

Figure 4.4 OCV Vent Port Plug O-ring Seal Test ................ 81 


\subsection{PAYLOAD PREPARATION}

\section{CAUTION}

If the payload pallet will be placed on a square pallet for subsequent movement by forklift, care must be taken to ensure all three pockets used for lifting with the Adjustable Center of Gravity Lift Fixture (ACGLF) rest on a flat surface. Failure to ensure this may result in pallet damage due to the weight of the ACGLF driving the pallet lift point through the pallet.

\section{NOTE}

This section provides the user with instructions for assembling a payload. Subsection 1.2, Preparing Drum Payload Assembly, Subsection 1.3, Preparing SWB Payload Assembly, and Subsection 1.4, Preparing TDOP Payload Assembly (and all included steps), must be completed, but may be done in any order IF radiological control steps are not bypassed.

\subsection{Basic Information}

1.1.1 Introduction - This procedure provides instructions for assembling the following contact-handled $(\mathrm{CH})$ packaging payloads:

- Drum payload assembly

- Standard Waste Box (SWB) assembly

- Ten-Drum Overpack (TDOP)

\subsubsection{References}

- U.S. Department of Energy, Safety Analysis Report for the TRUPACT-II Shipping Package

- TRUPACT-II Certificate of Compliance No. 9218

\subsubsection{Equipment}

- SWB ratchet straps or turnbuckles

- Drum payload pallet

- Guide tubes

- Stretch wrap

- Slip sheets

- Reinforcement plates

1.1.4 Prerequisite Actions - Each waste container shall be verified to meet $\mathrm{CH}$ packaging Transuranic Waste Authorized Methods for Payload Control (TRAMPAC) requirements before shipment. 


\subsection{Preparing Drum Payload Assembly}

1.2.1 Verify cotter pins are installed in lift pin assemblies on new style pallets.

1.2.2 Place clean pallet, right side up (i.e., large diameter plate on top), on floor or stretch wrap machine for use as the bottom support of the drum payload assembly.

1.2.3 Place slip sheet on top of pallet.

1.2.4 Verify guide-tube holes on slip sheet and pallet are aligned.

\section{NOTE}

The diameter of all drums, including locking ring, must be $\leq 24$ in. This dimension should not include the locking bolt. Tapping the locking ring with a hammer while torquing the locking ring nut may assist in ensuring the drum is tightly closed. Diameter of each layer of drums must not exceed 72 in.

\section{NOTE}

If shipping less than 14 loaded drums, empty dunnage drums must be used to form the payload while adhering to weight management practices (see Figure 1.1, Drum Placement). Dunnage drums shall have open vent ports (i.e., not filtered or plugged).

1.2.5 Verify at least one approved filter is installed in each loaded drum.

1.2.6 Verify all waste drums are properly labeled at three locations, about 120 degrees apart.

\section{NOTE}

In Step 1.2.7, at least one label on each drum (except the middle drum) must be visible when drums are assembled into a payload assembly.

1.2.7 Place seven drums on slip sheet using weight distribution shown in Figure 1.1.

1.2.8 Verify locking bolt on each drum is positioned between drum gaps that do not contain guide tubes.

1.2.9 Verify heaviest seven-pack is on bottom of drum payload assembly (see Figure 1.1).

1.2.10 Document completion of Step 1.2.9 per site requirements.

1.2.11 Stretch-wrap upper portion of drums with nine wraps so wraps extend down the sides of the drums a maximum of 22 in., with NO overlap on top of drums. 
1.2.12 Place reinforcing plate on top of first layer of drums.

1.2.13 Verify reinforcing plate guide tube holes are aligned with bottom slip sheet/pallet holes by inserting and removing guide tubes and adjusting assembly as required.

1.2.14 Apply nine additional wraps of stretch wrap so there is overlap on top of drums (see Figure 1.2, Drum Payload Assembly, Typical).

1.2.15 Place slip sheet on top of first layer of drums (over reinforcing plate) AND align white stripe with the slip sheet on lower assembly.

1.2.16 Verify guide tube holes are aligned with bottom slip sheet/pallet holes (if desired, guide tubes may be inserted to help maintain pallet alignment).

\section{NOTE}

In Step 1.2.17, at least one label on each drum (except the middle drum) must be visible when drums are assembled into a payload assembly.

1.2.17 Place second layer of seven drums on slip sheet using weight distribution shown in Figure 1.1.

1.2.18 Verify locking bolt (on each drum) is positioned between drum gaps which will not contain guide tubes.

1.2.19 Install bumper pads to top chine of the six exposed drums.

1.2.20 Stretch wrap upper portion of drums with nine wraps so wraps extend down the sides of drums a maximum of 22 in. with NO overlap on top of drums.

1.2.21 Place reinforcing plate on top of second layer of drums.

1.2.22 Verify guide tube holes are aligned with bottom slip sheet/pallet holes by inserting and removing guide tubes and adjusting assembly as required.

1.2.23 Apply nine additional wraps of stretch wrap so there is overlap on top of drums.

1.2.24 Verify at least one label on each drum (except the middle drum) is visible when drums are assembled into payload assembly.

1.2.25 If not already installed, insert guide tubes into drum payload assembly, adjusting upper assembly as required.

1.2.26 If beta-gamma and alpha surveys are required, perform surveys using site-specific procedures. 


\subsection{Preparing SWB Payload Assembly}

1.3.1 Verify at least two approved filters are installed in each SWB and remaining ports are plugged (if not filtered).

\section{NOTE}

If shipping only ONE loaded SWB, a second empty dunnage SWB must be used in the top position to form the payload. To allow for pressure changes, dunnage SWB shall have open vent ports (i.e., not filtered or plugged).

1.3.2 Verify SWBs are properly labeled.

\section{NOTE}

An SWB forklift adapter may be used in lieu of a crane/ACGLF.

1.3.3 Place heaviest SWB on floor.

1.3.4 Document completion of Step 1.3.3 per site requirements.

\section{CAUTION}

Operator shall verify two ACGLF counterweights are at 180 degrees and 000 degrees BEFORE lifting ACGLF or lid.

1.3.5 Place second SWB on top of first and align SWB edges.

1.3.6 Attach SWB turnbuckles or adjustable lifting slings (in three places) to top and bottom SWBs as follows:

- One on each outer lift clip on one side

- One on the middle clip on the opposite side (see Figure 1.3, SWB Adjustable Lifting Slings)

1.3.7 Install bumper pads (two on each rib) on the extreme ends of the top rib of the top SWB and on the bottom rib on the bottom SWB.

1.3.8 If beta-gamma and alpha surveys are required, perform surveys using site- specific procedures.

\subsection{Preparing TDOP Payload Assembly}

1.4.1 Verify at least nine approved filters are installed and remaining port is plugged (if not filtered).

1.4.2 Verify TDOP is properly labeled. 
1.4.3 Install bumper pads on the top and bottom rib of TDOP (four pads on each rib).

1.4.4 If beta-gamma and alpha surveys are required, survey using sitespecific procedures. 
Figure 1.1. Drum Placement

The following drum placement is recommended for two seven-pack assemblies:

Assembly of First Layer of Seven Drums Position Weight

1 Heaviest drum

$2 \quad$ Next heaviest drum

3 Third heaviest drum

4 Fourth heaviest drum

5 Fifth heaviest drum

6 Sixth heaviest drum

7 Last drum

Assembly of Second Layer of Seven Drums

\begin{tabular}{|c|c|}
\hline Position & Weight \\
\hline 8 & Heaviest drum \\
\hline 9 & Next heaviest drum \\
\hline 10 & Third heaviest drum \\
\hline 11 & Fourth heaviest drum \\
\hline 12 & Fifth heaviest drum \\
\hline 13 & Sixth heaviest drum \\
\hline 14 & Last drum \\
\hline
\end{tabular}
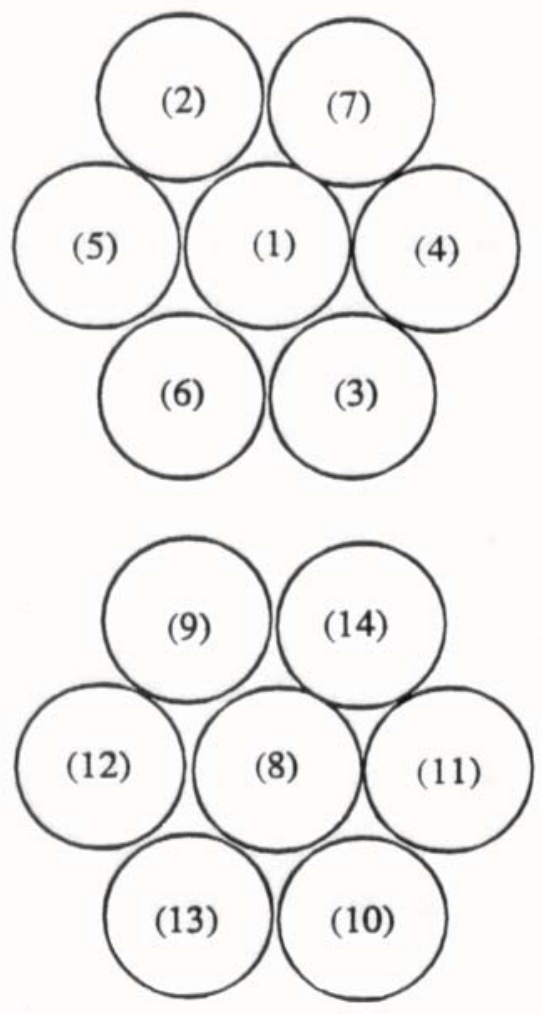
Figure 1.2. Drum Payload Assembly, Typical

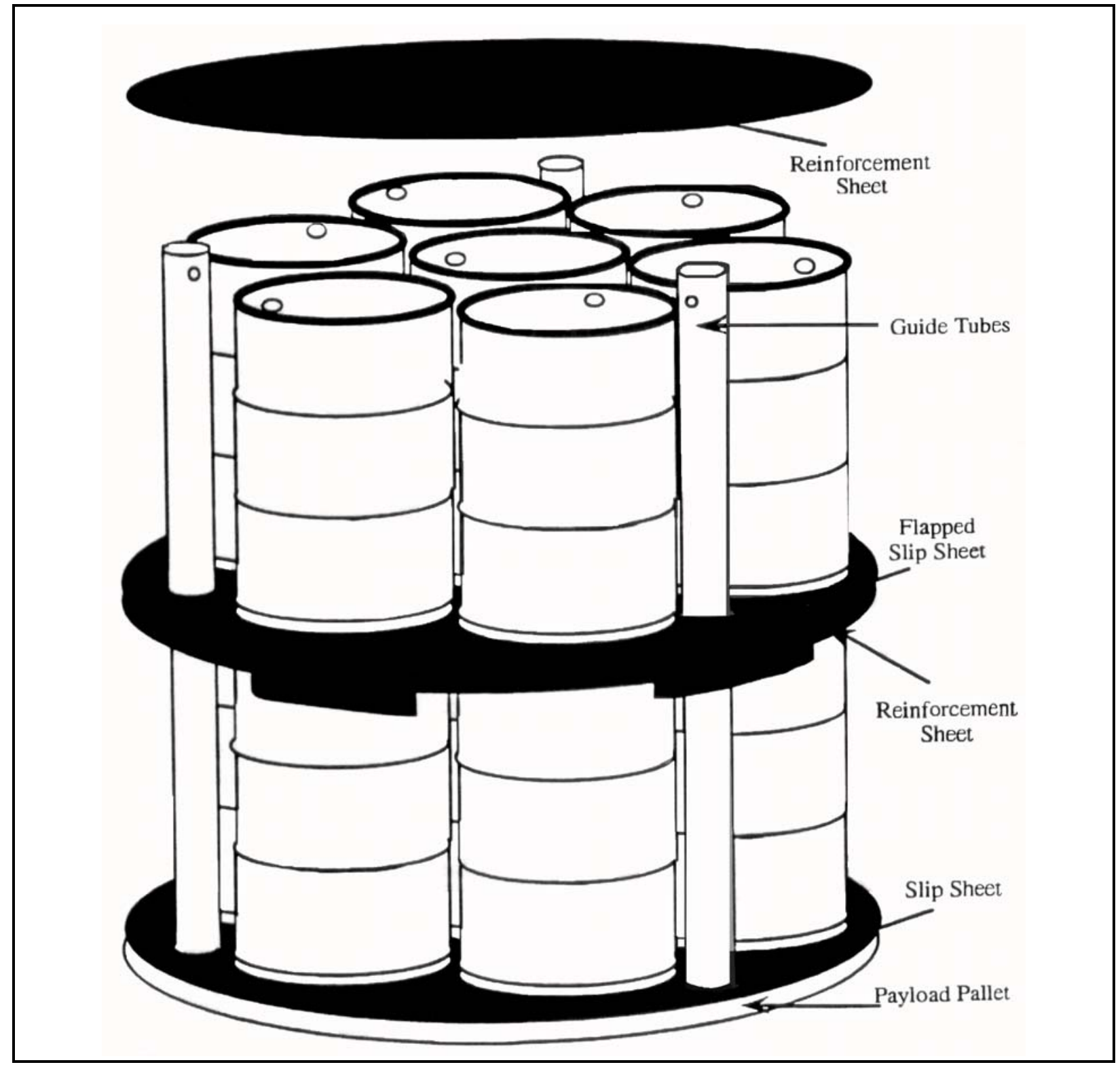


Figure 1.3. SWB Adjustable Lifting Slings

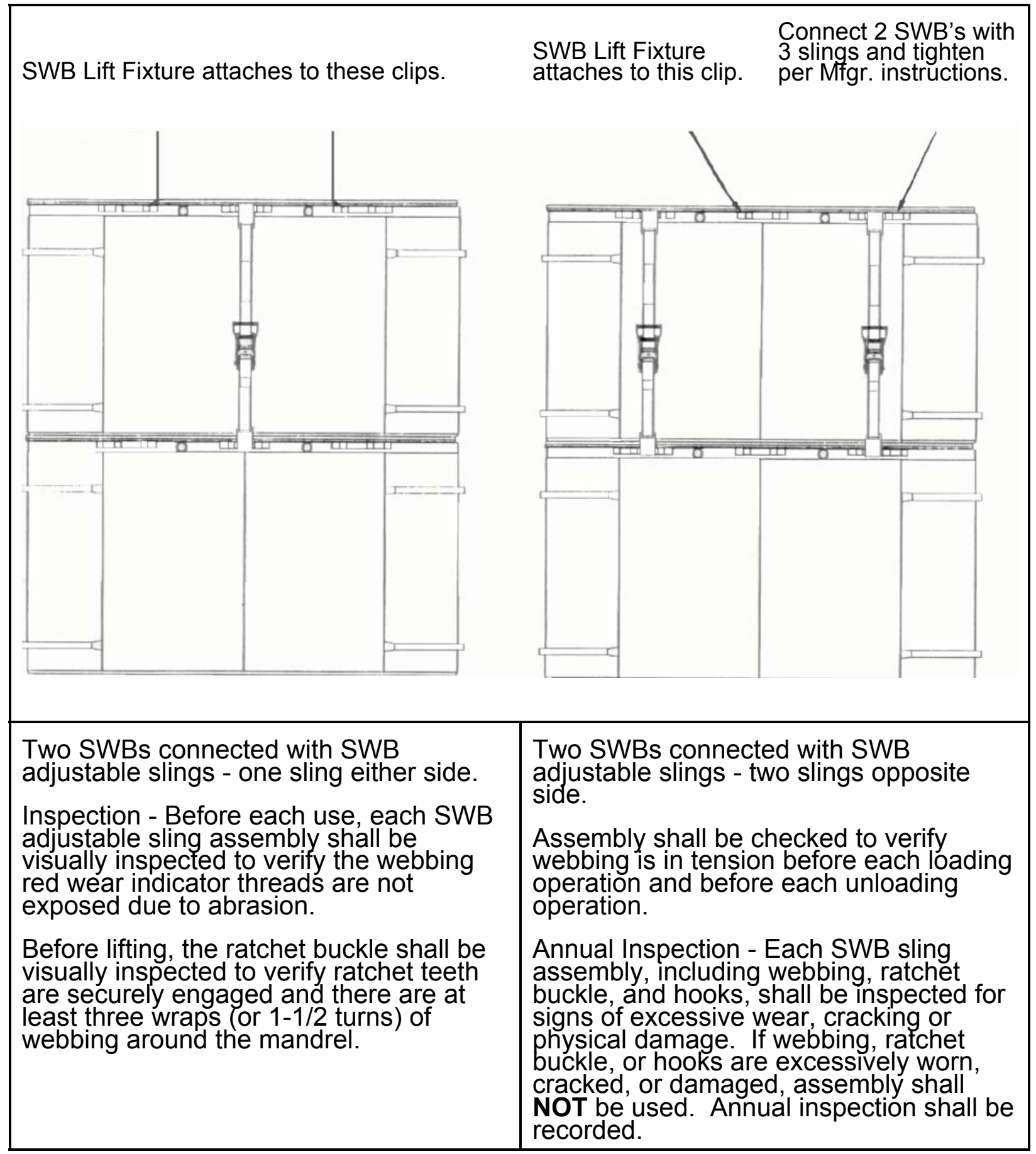




\subsection{NORMAL OPERATING INSTRUCTIONS}

\section{NOTE}

Torquing of components that are replaced using minor maintenance work instructions may be completed during the assembly step and do NOT require a second or repeat torque.

\section{NOTE}

Transport trailer operations, package loading and unloading from transport trailers, hoisting and rigging, equipment checkout and shutdown, and component inspection activities must be performed, but may be done in any order IF radiological control steps are not bypassed. Steps involving Outer Containment Assembly (OCA)/Inner Containment Vessel (ICV) lid removal/installation, payload removal/loading, and ICV evacuation backfill must be performed in sequence, except where noted.

\subsection{Basic Information}

2.1.1 Introduction - This procedure provides operating instructions for the TRUPACT-II CH waste packaging:

\subsubsection{References}

- 49 CFR Part 172, "Hazardous Materials Table, Special Provisions, Hazardous Materials Communications, Emergency Response Information, and Training Requirements"

- 49 CFR Part 173, "Shippers - General Requirements for Shipments and Packagings"

- U.S. Department of Energy, Safety Analysis Report for the TRUPACT-II Shipping Package

- TRUPACT-II Certificate of Compliance No. 9218

- TRUPACT-Il Authorized Methods for Payload Control (TRAMPAC)

- DOE/WIPP 02-3183, CH Packaging Program Guidance

- DOE/WIPP 02-3185, CH Packaging Maintenance Manual

\subsubsection{Equipment}

- Calibrated Measuring and Test Equipment

- Pressure/vacuum gauge, $30 \mathrm{in}$. $\mathrm{Hg}$ to $30 \mathrm{psig}$

- Torque wrench with 55 to 65 pound-inches (lb-in) range 
- Torque wrench with 30 to 50 pound-feet (lb-ft) range

- Crane load cell, 10,000-lb minimum rating

- Other Equipment

- ICV/Outer Containment Vessel (OCV) vent port plug removal/pressure relief tool

- Miscellaneous hardware and vacuum assembly connections

- Vacuum pump

- ICV/OCV outer vent port plug removal and installation tool

- Consumable Materials

- Vacuum grease

- Nickel bearing lubricant

- Denatured alcohol

- Rags

- $250 \mathrm{ft}^{3}$ (minimum) of dry nitrogen gas

- Evacuation/Backfill Cart

- Dry vacuum pump (oil-free) with a minimum flow rate of $11.9 \mathrm{scfm}$ and an ultimate base pressure of $50 \mathrm{mTorr}$ or less.

- Evacuation/backfill line, 1 in. i.d. tubing (length as required)

- One 1 in. ball valve

- Compressed gas regulator (capable of regulating to $1 \mathrm{psi}$ increments)

- Quick connect fitting, P/N SSQC8-D-810

- Tube reducer, P/N SS-810-R-16

- Flow meter capable of $75 \mathrm{cfh}$

\subsubsection{Precautions and Limitations}

- Failure to rotate counterweights on ACGLF to the balance position may cause ACGLF to swing uncontrollably.

- Pressure transducer and controller installed in evacuation/backfill cart must be energized at least 30 minutes before initiating evacuation process in Subsection 2.17, ICV Lid Installation. 


\subsection{Packaging (Empty) Receipt}

\section{NOTE}

Packaging loading/unloading operations shall only be performed in a dry environment. If precipitation occurs during outdoor operations, OCV and ICV cavities shall be covered to prevent precipitation from entering the package interior cavities. If precipitation does enter interior cavities, all freestanding water shall be removed before shipment, and handled according to the site's liquid waste management procedures.

2.2.1 Record OCA serial number on Attachment 1, LANL High Wattage CH Packaging Receipt and Inspection Data Sheet.

\section{SIGN-OFF}

2.2.2 Verify site representative performed the following and initial Attachment 1:

- Released packaging for loading

- Validated shipping documents

- Inspected packaging for damage

- Verified package nameplate is proper for contents being shipped

\section{SIGN-OFF}

2.2.3 Verify packaging maintenance is current by checking maintenance labels next to name plate, and initial Attachment 1.

\section{SIGN-OFF}

2.2.4 Check for "Leak Test Required" tag near OCA vent port.

2.2.5 If "Leak Test Required" tag is present, remove tag and forward to supervisor to ensure leak test report will be sent to WIPP Management and Operating (M\&O) contractor $\mathrm{CH}$ Packaging Maintenance Engineer.

\section{CAUTION}

A physical check should be made to verify air bags on the trailer have fully inflated before the trailer is moved. If air bags are not fully inflated, the tires may rub on bottom of the rear package.

2.2.6 Position transport trailer in designated parking area.

2.2.7 Lower trailer jacks (landing gear), ensuring trailer is level. 
2.2.8 Install wheel chocks.

2.2.9 Install trailer stands on freestanding trailers.

2.3 Releasing Tie-downs and Removal of Packaging from Trailer

2.3.1 IF packaging will NOT be removed from trailer for loading operations, THEN GO TO Subsection 2.4, OCA Lid Removal.

2.3.2 Loosen tie-down adjusting nut(s).

2.3.3 Lift tie-down assemblies from tie-down lugs.

2.3.4 Rotate assemblies away from lugs.

2.3.5 Lower assemblies completely to trailer brackets.

2.3.6 Rotate forklift pocket covers (4) to UP position, OR remove covers and store in designated area.

2.3.7 If necessary, remove moisture from packaging.

\section{CAUTION}

Forklift tip-back beyond level may damage package exterior surface.

2.3.8 Transfer packaging to designated area.

\subsection{OCA Lid Removal}

2.4.1 Prepare OCA lid by removing the following:

- OCA lid lift pocket covers

- OCV lock ring bolts (6)

- OCA test port access plug and thermal plug

- OCA vent port access plug and thermal plug

2.4.2 Remove OCV seal test port plug.

2.4.3 Remove OCV vent port cover.

2.4.4 Remove OCV vent port plug.

2.4.5 Attach crane to ACGLF.

2.4.6 Lower ACGLF legs into lift pockets on OCA lid. 
2.4.7 Verify ACGLF legs are locked.

2.4.8 Install OCV vent port tool.

2.4.9 Connect vacuum line to vent port tool.

2.4.10 Start vacuum pump and evacuate to 3 to $15 \mathrm{in}$. $\mathrm{Hg}$. vacuum gauge.

2.4.11 Rotate OCV lock ring to UNLOCKED position.

2.4.12 Stop vacuum pump.

2.4.13 Disconnect vacuum line from vent port tool.

2.4.14 Remove vent port tool.

2.4.15 Vent OCV to atmosphere.

\section{CAUTION}

Operator shall verify two ACGLF counterweights are at 180 degrees and 000 degrees BEFORE lifting ACGLF or lid.

\section{CAUTION}

Do NOT exceed 7,500 lb load cell reading when weight of ACGLF is zeroed out. Do NOT exceed $10,000 \mathrm{lb}$ load cell reading when weight of ACGLF is included.

2.4.16 Remove OCA lid.

2.4.17 IF lid does not lift off, THEN perform the following:

[A] Contact supervisor.

[B] GO TO Subsection 3.2, Using Heat Guns, or Subsection 3.3, Pressurizing with Nitrogen or Compressed Air, and attempt to remove lid.

[C] IF lid lifts off, THEN RETURN TO Step 2.4.18.

2.4.18 Place OCA lid on storage stand. 


\subsection{ICV Lid Removal}

\section{CAUTION}

Operator shall verify two ACGLF counterweights are at 180 degrees and 000 degrees BEFORE lifting ACGLF or lid.

2.5.1 Attach crane to ACGLF.

2.5.2 Lower ACGLF legs into lift pockets on ICV lid.

2.5.3 Verify ACGLF legs are locked.

2.5.4 Prepare ICV lid by removing the following:

- ICV lock ring bolts (3)

- ICV vent port cover

- ICV seal test port plug

2.5.5 Remove ICV outer vent port plug.

2.5.6 Remove ICV inner vent port plug.

2.5.7 Install ICV vent port tool.

2.5.8 Connect vacuum line to vent port tool.

2.5.9 Start vacuum pump and evacuate to 3 to $15 \mathrm{in}$. $\mathrm{Hg}$. vacuum gauge.

2.5.10 Rotate ICV lock ring to UNLOCKED position.

2.5.11 Stop vacuum pump.

2.5.12 Disconnect vacuum line from vent port tool.

2.5.13 Remove vent port tool.

2.5.14 Vent ICV to atmosphere. 


\section{CAUTION}

Do NOT exceed 5,000-lb load cell reading when weight of ACGLF is zeroed out. Do NOT exceed 7,500-lb load cell reading when weight of ACGLF is included.

2.5.15 Remove ICV lid using ACGLF and crane.

2.5.16 IF lid does not lift off ICV,

THEN perform the following:

[A] Contact supervisor.

[B] GO TO Subsection 3.2, or Subsection 3.3, and attempt to remove lid.

[C] IF lid lifts off, THEN RETURN TO Step 2.5.17.

2.5.17 Place ICV lid on storage stand.

\section{NOTE}

Use of ACGLF with short legs to remove items from ICV is NOT permitted.

2.5.18 Remove any payload pallets, guide tubes, slip sheets, reinforcement sheets, dunnage containers, etc.

2.6 Preloading/Shipping Operational Checks and Examinations

2.6.1 Radiological Control Technician (RCT), IF surveys for items in Steps 2.7.1, 2.8.1, or 2.9.1 were completed previously AND results were below contamination limits, THEN enter applicable data for each Step on Attachment 1.

2.6.2 RCT, IF surveys were NOT completed previously, THEN GO TO applicable subsection(s) below:

- Subsection 2.7 for OCA Lid Inspection and Cleaning

- Subsection 2.8 for ICV Lid Inspection and Cleaning

- Subsection 2.9 for OCA Body Inspection and Cleaning 


\section{NOTE}

Subsections 2.7, through 2.13, ICV Cavity Inspection, (and included steps) MUST be completed, but may be done in any order IF radiological control steps are not bypassed.

2.7 OCA Lid Inspection and Cleaning

2.7.1 RCT, IF survey was not completed previously,

THEN survey interior and exterior of OCA lid and record applicable data on Attachment 1.

\section{SIGN-OFF}

2.7.2 Inspect OCA lid for the following:

- Visible deformation

- Dents or abnormal flat spots $>1 / 2$ inch

- Abnormal scratches or gouges

- Obvious punctures, tears, or cracks in exposed welds

- Plastic burn out plugs (3) in place and intact

- Fiberglass tubes in place

- Distortions or cracks on or around lifting attachments

- Lid lift pocket covers attached and serviceable

- OCV locking Z-flange screws in place and tight

- Guide plates and screws in place and tight

2.7.3 Remove foreign material from the following:

- Lock ring

- Sealing surfaces

- Test port access threads

2.7.4 Initial Attachment 1 to document OCA lid components and hardware are satisfactory.

\section{SIGN-OFF}

2.8 ICV Lid Inspection and Cleaning

2.8.1 RCT, IF survey was NOT completed previously, THEN survey interior and exterior of ICV lid and record applicable data on Attachment 1.

\section{SIGN-OFF}


2.8.2 Inspect ICV lid for the following:

- Visible deformation

- Punctures

- Abnormal scratches or gouges

- Distortions on or around lifting attachments

- Upper spacer and screws installed and tight

- Foam debris seal installed and intact

- Lock ring undamaged

2.8.3 Remove foreign material from the following:

- Lock ring flange

- Debris seal

- Sealing surfaces

2.8.4 Inspect ICV wiper O-ring for the following:

- Cleanliness (no visible dirt or debris)

- Damage (voids, cracks, and gouges)

2.8.5 IF O-ring is damaged,

THEN GO TO work instruction WI-CH.02, Replacement of ICV/OCV Upper \& Lower Main O-rings, ICV Wiper, replace O-ring and RETURN TO Step 2.8.7.

2.8.6 IF O-ring is removed for inspection/cleaning, THEN apply vacuum grease, as required, before installing.

2.8.7 Initial Attachment 1 to document ICV lid components and hardware are satisfactory.

\section{SIGN-OFF}

2.9 OCA Body Inspection and Cleaning

2.9.1 RCT, IF survey was NOT completed previously, THEN survey OCA body exterior and ICV body interior and record applicable data on Attachment 1.

\section{SIGN-OFF}

2.9.2 Remove upper and lower main O-rings and set aside for cleaning and inspection. 
2.9.3 Inspect OCA body for the following:

- Obvious punctures or tears

- Obvious cracks in exposed welds

- Dents or abnormal flat spots $>1 / 2$ inch

- Abnormal scratches or gouges

- Burn out plugs (6) in place and intact

- Forklift pocket inserts (8) intact and threads undamaged

- Lock ring threaded inserts (6) intact and threads undamaged

- Tears or excessive wear on ceramic fiber gasket

2.9.4 Remove foreign material from the following:

- Test port threads

- Vent port threads

- Lock ring flange

- O-ring grooves

- Sealing surfaces

2.9.5 Initial Attachment 1 to document OCA body inspection is satisfactory.

\section{SIGN-OFF}

2.10 OCA Components Inspection and Cleaning

2.10.1 Clean and inspect the following for deformation, scratches or burrs:

- OCV vent port plug and O-rings

- OCV vent port cover and O-rings

- OCV test port plug and O-ring

- Lock ring bolts (6)

- OCA test port access plug

- OCA vent port access plug

2.10.2 IF O-rings are damaged,

THEN GO TO WI-CH.01, Replacement of ICV/OCV Small Plugs, O-rings, and Gaskets, replace O-ring(s) and RETURN TO

Step 2.10.4.

2.10.3 Apply a light coat of vacuum grease to the following:

- OCV vent port plug threads and sealing O-ring

- OCV vent port cover threads and sealing O-ring

- OCV test port plug threads and O-ring

2.10.4 Verify annulus debris shield is installed and intact.

2.10.5 Lightly coat the following with nickel bearing lubricant:

- OCA lock ring bolt threads (6)

- OCA test port access plug threads

- OCA vent port access plug threads 
2.10.6 Clean and inspect upper and lower main O-rings for tears, nicks, flat spots or cracks.

2.10.7 IF O-rings are damaged, THEN GO TO WI-CH.02, replace O-ring(s) and RETURN TO Step 2.10.9.

\section{NOTE}

Lubrication and installation of upper and lower main O-rings may be performed after Step 2.16.16, but before Subsection 2.19, OCA Lid Installation.

2.10.8 Lubricate upper and lower main O-rings with a light coat of vacuum grease.

2.10.9 Install upper and lower main O-rings.

2.10.10 Initial Attachment 1 to document OCA component and hardware inspections are satisfactory.

\section{SIGN-OFF}

2.11 ICV Body Inspection and Cleaning

2.11.1 Remove upper and lower main O-rings and set aside for cleaning and inspection.

2.11.2 Remove foreign material from the following:

- Test port threads

- Vent port threads

- Lock ring flange

- O-ring grooves

- Filter ports

- Sealing surfaces

2.11.3 Inspect the following for deformation, scratches or burrs:

- Upper and lower O-ring grooves

- Vent port threads

- Seal test port threads

- Lock ring flange

- Lower spacer installed with no tears in skin

- Lower spacer fasteners installed

2.11.4 Initial Attachment 1 to document ICV body inspection is satisfactory.

\section{SIGN-OFF}




\subsection{ICV Components Inspection and Cleaning}

2.12.1 Clean and inspect the following for deformation, scratches or burrs:

- ICV vent port cover and seal

- ICV vent port outer plug and O-ring

- ICV vent port inner plug and O-ring

- ICV seal test port plug and O-ring

- ICV lock ring bolts (3)

2.12.2 IF O-rings are damaged, THEN GO TO WI-CH.01, replace O-ring(s) and RETURN TO Step 2.12.4.

2.12.3 Apply a light coat of vacuum grease to the following:

- ICV vent port cover threads (and O-ring if installed)

- ICV vent port outer plug threads and O-ring

- ICV vent port inner plug threads and O-ring

- ICV seal test port plug threads and O-ring

2.12.4 Coat ICV lock ring bolt threads (3) lightly with nickel bearing lubricant.

2.12.5 Clean upper and lower main O-rings and inspect for tears, nicks, flat spots or cracks.

2.12.6 IF O-rings are damaged, THEN GO TO WI-CH.02, replace O-ring(s) and RETURN TO Step 2.12.8.

\section{NOTE}

Lubrication and installation of upper and lower main O-rings may be performed after Step 2.16.16, but before Subsection 2.17.

2.12.7 Lubricate upper and lower main O-rings with a light coat of vacuum grease.

2.12.8 Install upper and lower main O-rings.

2.12.9 Initial Attachment 1 to document ICV components and hardware inspections are satisfactory.

\section{SIGN-OFF}

\subsection{ICV Cavity Inspection}

2.13.1 Check ICV cavity for water by visually inspecting the absorbent material inserted into hole in lower spacer assembly. 


\section{NOTE}

Disposal of absorbent material and water will be at direction of RCT.

2.13.2 IF water is found in ICV, THEN perform ONE of the following, if possible:

- Remove water using wet/dry vacuum

- Remove water using absorbent material attached to end of rod

2.13.3 IF water is inside ICV, THEN, GO TO Subsection 3.1, Empty ICV Assembly Removal, perform steps and RETURN TO Step 2.13.4.

2.13.4 Initial Attachment 1 to document ICV is free of water.

\section{SIGN-OFF}

\subsection{Pre-loading Operations}

Verify all pre-loading cleaning and inspections are complete and initial Attachment 1.

\section{SIGN-OFF}

2.15 Packaging Receipt and Inspection Data Sheet Validation

Supervisor, review/validate entries on Attachment 1 and sign.

\section{SIGN-OFF}

\subsection{Loading Payload Assembly}

\section{NOTE}

For shipments to WIPP, shipper should verify each payload container number has been entered into the WIPP Waste Information System (WWIS), and verify the shipment has been approved by WIPP WWIS Data Administrator. Verification is needed to preclude loss of any portion of the allowable 5-day shipping period.

2.16.1 Record OCA serial number on Attachment 2, LANL High Wattage $\mathrm{CH}$ Packaging Loading Data Sheet, and Attachment 4, LANL High Wattage Loaded Package Receipt and Processing Data Sheet.

\section{SIGN-OFF}

2.16.2 Record shipment number, trailer number and package number(s) on Attachment 3, LANL High Wattage Loaded CH Package Trailer Data Sheet. 


\section{CAUTION}

Operator shall verify two ACGLF counterweights are at 180 degrees and 000 degrees BEFORE lifting ACGLF or lid.

2.16.3 Attach appropriate legs/adapter to ACGLF.

2.16.4 Lower ACGLF long legs into drum payload assembly guide tubes using crane and ACGLF until red stripes are no longer visible, OR lower SWB or TDOP adaptor until no load is indicated on crane load cell.

2.16.5 Lock ACGLF legs,

OR attach SWB lift fixture to upper SWB or TDOP adaptor to TDOP, as applicable.

2.16.6 Raise payload 2 to 6 in.

2.16.7 If necessary, balance payload using counterweight controls at ACGLF console until a reading of \pm 0.5 degrees is obtained.

2.16.8 Record payload assembly weight (i.e., drums [or SWBs, TDOP] + pallet + guide tubes + slip sheets) on Attachment 2 .

\section{SIGN-OFF}

2.16.9 Obtain packaging weight from WIPP WWIS Packaging Reference Data Table.

2.16.10 Record empty packaging weight on Attachment 2.

\section{SIGN-OFF}

2.16.11 Add two previously recorded weight values to calculate total package weight and record on Attachment 2.

\section{SIGN-OFF}

2.16.12 Verify total loaded package weight does not exceed 19,250 lb.

2.16.13 Raise and position payload assembly over ICV cavity using crane and ACGLF.

2.16.14 Verify payload is centered over ICV BEFORE lowering load. 


\section{CAUTION}

Care should be exercised to avoid hitting, scraping or binding the payload assembly against the ICV body flange and internal surface.

2.16.15 Lower payload assembly into ICV.

2.16.16 Record weight positions of ACGLF on top of payload near leg opposite the electrical junction boxes.

\section{CAUTION}

Operator shall verify two ACGLF counterweights are at 180 degrees and 000 degrees BEFORE lifting ACGLF or lid.

2.16.17 Remove ACGLF/adaptor from payload.

\section{NOTE}

Valves $\mathrm{V}-1$ and $\mathrm{V}-2$ may be cycled as necessary to obtain system pressure readings in Subsections 2.17 and 2.18 .

2.17 ICV Lid Installation

2.17.1 Match ICV lid and body serial numbers and record ICV serial number on Attachment 2.

\section{SIGN-OFF}

2.17.2 Record torque wrench serial numbers and calibration due date on Attachment 2.

\section{SIGN-OFF}

\section{CAUTION}

Operator shall verify two ACGLF counterweights are at 180 degrees and 000 degrees BEFORE lifting ACGLF or lid.

\subsubsection{Attach crane to ACGLF.}

2.17.4 Lower ACGLF legs into lifting pockets on ICV lid.

2.17.5 Verify ACGLF legs are locked. 
2.17.6 Align UNLOCKED arrows and install ICV lid onto ICV body using crane and ACGLF.

2.17.7 Verify inner vent port plug is retracted into ICV vent port tool.

2.17.8 Install ICV vent port tool into ICV vent port.

\section{NOTE}

Steps 2.17.9 through 2.18.12 incorporate the use of an evacuation/backfill cart identified in Step 2.1.3.

2.17.9 Install Radiation Assessment Filter (RAF) assembly (with a filter installed) on the ICV vent port tool.

2.17.10 Verify vent port isolation valve $\mathrm{V}-4$ is open.

2.17.11 Record ambient atmospheric pressure on Attachment 2.

\section{SIGN-OFF}

2.17.12 Verify pressure transducer isolation valve $(\mathrm{V}-1)$ is open.

2.17.13 Verify vacuum pump isolation valve $(\mathrm{V}-2)$ is open.

2.17.14 Verify nitrogen isolation valve $(\mathrm{V}-3)$ is closed.

2.17.15 Start vacuum pump and reduce pressure to a minimum of 3 in. (76 Torr), Hg LESS than the ambient pressure recorded in Step 2.17.11.

2.17.16 Rotate ICV lock ring to LOCKED position.

2.17.17 Close valve V-1.

2.17.18 Wait until 12 hours (minimum) have passed.

2.17.19 Open valve $\mathrm{V}-1$ and monitor pressure.

2.17.20 If pressure is greater than 500 mTorr, continue pumping until pressure is less than 500 mTorr.

2.17.21 Record final pressure on Attachment 2.

\section{SIGN-OFF}

2.17.22 Close valve V-2 and stop vacuum pump. 
2.17.23 Immediately record $T_{\text {start }}$ on Attachment 2 and Attachment 9, Time and Date Data Sheet for Shipment of Content Code LA 154.

\section{SIGN-OFF}

2.17.24 Close valve V-4 and remove RAF filter and screens from the RAF housing assembly.

2.17.25 Reassemble RAF housing assembly, excluding the filter and screens.

\section{HOLD POINT}

2.17.26 RCT, survey filter for contamination following site-specific procedures and initial Attachment 4.

\section{SIGN-OFF}

2.17.27 Calculate $T_{\text {unload_120 }}=T_{\text {start }}+120$ hours and record on Attachment 4.

\section{SIGN-OFF}

\subsection{Nitrogen Backfill}

2.18.1 Open valve V-4.

2.18.2 Open valve V-3.

2.18.3 Open valve on nitrogen supply source.

2.18.4 Adjust flow meter to a flow rate of about $60 \mathrm{cfh}$.

\section{CAUTION}

Do not allow pressure inside ICV to exceed the ambient atmospheric pressure recorded in Step 2.17.11 by more than 25 Torr.

2.18.5 Monitor pressure inside ICV.

2.18.6 When pressure inside ICV is equal to the ambient atmospheric pressure recorded in Step 2.17.11 (+25, -5 Torr), close valve V-3.

2.18.7 Adjust flow regulator fully counterclockwise and close valve on top of nitrogen supply source.

2.18.8 Allow a 2-hour stabilization period. Monitor pressure inside ICV. If pressure inside ICV does not decrease below the ambient 
atmospheric pressure recorded in Step 2.17.11 (within 5 Torr), after the 2-hour stabilization period, the backfill process is complete. GO TO Step 2.18.10.

2.18.9 IF pressure inside ICV decreases below the ambient atmospheric pressure recorded in Step 2.17.11 (within 5 Torr), within the 2-hour stabilization period,

THEN perform the following:

[A] Open valve on nitrogen supply source.

[B] Open valve V-3.

[C] Adjust flow regulator slowly to bring pressure inside ICV to the ambient atmospheric pressure recorded in Step 2.17.11 (+25, -5 Torr).

[D] Close valve on nitrogen supply.

2.18.10 When backfill process is complete, close valve $\mathrm{V}-1$.

2.18.11 Install ICV inner vent port plug.

2.18.12 Disconnect vacuum line from ICV vent port tool.

2.18.13 Remove ICV vent port tool.

2.18.14 Torque inner vent port plug to 55 to $65 \mathrm{lb}$-in. and initial Attachment 2 .

\section{SIGN-OFF}

2.18.15 Install ICV lock ring bolts (3).

2.18.16 Torque each ICV lock ring bolt to 28 to $32 \mathrm{lb}$-ft and initial Attachment 2.

\section{SIGN-OFF}

2.18.17 Perform ICV preshipment leakage rate test per Section 4.0, Preshipment Leakage Rate Testing and initial Attachment 2.

\section{SIGN-OFF}


2.19 OCA Lid Installation

2.19.1 Match OCA lid and body serial numbers and initial Attachment 2 .

SIGN-OFF

\section{CAUTION}

Operator shall verify two ACGLF counterweights are at 180 degrees and 000 degrees BEFORE lifting ACGLF or lid.

2.19.2 Lower ACGLF legs into lifting pockets on OCA lid.

2.19.3 Verify ACGLF legs are locked.

2.19.4 Install OCA lid onto OCA body.

2.19.5 Verify OCV vent port plug is retracted into OCV vent port tool.

2.19.6 Install OCV vent port tool into OCV vent port.

2.19.7 Connect vacuum line to OCV vent port tool.

2.19.8 Start vacuum pump and evacuate to 3 to $15 \mathrm{in}$. $\mathrm{Hg}$. vacuum gauge.

2.19.9 Rotate OCV lock ring to LOCKED position.

2.19.10 Stop vacuum pump.

2.19.11 IF existing connection will be used for OCV leak test, THEN GO TO Step 2.19.13.

2.19.12 Disconnect vacuum line from vent port tool.

2.19.13 Install OCA lock ring bolts (6).

2.19.14 Torque each OCA lock ring bolt to 28 to $32 \mathrm{lb}$-ft and initial Attachment 2.

\section{SIGN-OFF}

2.19.15 GO TO Section 4.0, perform OCV preshipment leakage rate test, RETURN TO Step 2.19.16 and initial Attachment 2. 
2.19.16 Install OCA lid lift pocket covers.

2.19.17 Install tamper-indicating security seal in both lock ring bolt on OCA lock ring assembly and OCA vent port access plug.

2.19.18 Record tamper-indicating security seals serial numbers on Attachment 2.

\section{SIGN-OFF}

2.19.19 Supervisor, review/validate entries on Attachment 2 and sign.

\section{SIGN-OFF}

2.20 Installation of Package on Transport Trailer

\section{NOTE}

When loading packages on trailer, or loading payload into packaging that is already on trailer, the following applies:

- Packages having a gross weight difference (heaviest to lightest) of $2,000 \mathrm{lb}$ or less can be considered equal and do not require a specific sequence for positioning on the trailer.

- Packages having a gross weight difference (heaviest to lightest), greater than 2,000 pounds shall be positioned on the trailer as follows:

\begin{tabular}{|l|l|l|l|l|}
\hline \multirow{4}{*}{$\begin{array}{l}\text { TRAILER } \\
\text { FRONT }\end{array}$} & *1. Heaviest & Medium & Lighter & \\
\cline { 2 - 4 } & 2. Heaviest & Lighter & Medium & \\
\cline { 2 - 4 } & *3. Heaviest & Lighter & None & REAILER \\
\cline { 2 - 4 } & 4. Lighter & Heaviest & None \\
\cline { 2 - 4 } & 5. Heaviest & None & None & \\
\hline \multicolumn{2}{|l|}{ * Preferred method }
\end{tabular}

2.20.1 Verify the following and record on Attachment 3:

- Shipment number

- Trailer number

- Package number(s)

\section{SIGN-OFF}

2.20.2 Verify trailer inspection is current. 
2.20.3 Record trailer inspection date on Attachment 3.

\section{SIGN-OFF}

2.20.4 Inspect tie-downs for the following:

- Damage

- Defects

2.20.5 IF packaging was removed for loading operations, THEN perform the following:

[A] Position transport trailer in designated area.

[B] Lower trailer jacks (landing gear), ensuring trailer is level.

[C] Install wheel chocks.

[D] Install jack stands on freestanding trailers.

\section{CAUTION}

Forklift tip-back beyond level may damage package exterior surface.

[E] Transport package to transport trailer.

[F] Load package designated for position \#1 onto trailer with vent port on driver side of trailer.

[G] If applicable, load package designated for position \#2 onto trailer with vent port on driver side of trailer.

[H] If applicable, load package designated for position \#3 onto trailer with vent port on driver side of trailer.

[1] Install four tie-down assemblies for each package loaded on trailer.

[J] Install package forklift pocket access covers.

2.20.6 Record package positions and weights on Attachment 3.

\section{SIGN-OFF}


2.20.7 Record total weight of all loaded packages as payload weight on Attachment 3.

\section{SIGN-OFF}

2.20.8 Verify package(s) complies with 49 CFR Part 172, Subpart D "Marking," Subpart E, "Labeling," and Subpart F, "Placarding," and initial Attachment 3.

\section{SIGN-OFF}

2.20.9 Transfer information to shipping papers as required for specific shipment.

2.20.10 Verify shipping papers comply with 49 CFR Part 172, Subpart C, "Shipping Papers" and initial Attachment 3.

\section{SIGN-OFF}

2.20.11 Record date and time (as $\mathrm{T}_{\text {ship }}$ ) shipment is ready to depart from LANL on Attachment 3 and Attachment 9.

\section{SIGN-OFF}

2.20.12 Calculate $T_{\text {staging }}=T_{\text {ship }}-T_{\text {start }}=\ldots$ Hours and record on Attachment 3 and Attachment 9.

\section{SIGN-OFF}

2.20.13 Verify $T_{\text {staging }}<24$ hours and initial both Attachment 3 and Attachment 9.

\section{SIGN-OFF}

2.20.14 If $\mathrm{T}_{\text {staging }}>24$ hours, GO TO Subsection 3.4, Venting.

2.20.15 TCO, review/validate entries on Attachment 9 and sign.

2.20.16 Supervisor, perform the following:

[A] Review/validate entries on Attachment 3 and sign.

[B] Copy Attachments 2, 3, 4, and 9 to include with shipping papers.

[C] Notify WIPP Central Monitoring Room of pending shipment. 


\subsection{Package (Loaded) Receipt}

\section{NOTE}

Package unloading operation shall only be performed in a dry environment. If precipitation occurs during outdoor unloading or loading operations, OCV and ICV cavities shall be covered to prevent precipitation from entering interior cavities. If precipitation does enter interior cavities, freestanding water shall be removed before shipment, and handled according to the site's liquid waste management procedures.

2.21.1 Verify OCA serial number is recorded on Attachment 4.

\section{SIGN-OFF}

2.21.2 Record $\mathrm{T}_{\text {arrive }}$, time and date on Attachment 4 and Attachment 10.

\section{SIGN-OFF}

2.21.3 Calculate $T_{\text {unload_24 }}=T_{\text {arrive }}+24$ and record on Attachment 4.

\section{SIGN-OFF}

2.21.4 Notify site representative that shipment shall be unloaded before either $T_{\text {unload_120, }}$ or $T_{\text {unload_24 }}$, whichever is sooner, and record choice as $T_{\text {final }}$ on Attachment 4 .

\section{SIGN-OFF}

2.21.5 Verify site representative has performed the following and initial Attachment 4:

- Validated shipping documents

- Inspected package(s) for damage

- Released package(s) for unloading

\section{SIGN-OFF}

2.21.6 Survey package for external radiation and contamination using sitespecific procedures and initial Attachment 4.

\section{SIGN-OFF}




\section{CAUTION}

A physical check shall be made to verify air bags on the trailer have fully inflated before the trailer is moved. If air bags are not fully inflated, the tires may rub on the bottom of the rear TRUPACT-II.

2.21.7 Position transport trailer in designated area.

2.21.8 Lower trailer jacks (landing gear), ensuring trailer is level.

2.21.9 Install wheel chocks.

2.21.10 Install trailer stands on freestanding trailers.

2.22 Releasing Tie-downs and Removal of Package from Trailer

2.22.1 IF package will NOT be removed from trailer, THEN GO TO Subsection 2.23, OCA Lid Removal.

2.22.2 Loosen tie-down adjusting nut(s).

2.22.3 Lift tie-down assemblies from tie-down lugs.

2.22.4 Rotate away from lugs.

2.22.5 Lower completely to trailer brackets.

2.22.6 Rotate four forklift pocket covers to UP position, OR remove four covers and store in designated area.

2.22.7 If required, remove moisture from package before transport.

\section{CAUTION}

Forklift tip-back beyond level may damage package exterior surface.

2.22.8 Transfer package to unloading area.

\subsection{OCA Lid Removal}

2.23.1 Remove and dispose of security seals.

2.23.2 If seal is broken or missing, follow applicable site policy. 
2.23.3 Remove the following components to prepare OCA lid for removal:

- OCA lid lift pocket covers

- OCA test port access plug and thermal plug

- OCA vent port access plug and thermal plug

2.23.4 If OCA lid is turned so that OCA seal test port plug is not accessible, GO TO Step 2.23.6.

2.23.5 Verify OCV seal test port plug is fully seated.

2.23.6 Remove OCV vent port cover.

2.23.7 Install OCV vent port tool.

2.23.8 Retrieve OCV vent port plug into vent port tool.

2.23.9 Connect vacuum line to vent port tool.

2.23.10 Start vacuum pump and evacuate to 3 to $15 \mathrm{in}$. $\mathrm{Hg}$. vacuum gauge.

2.23.11 Remove OCA lock ring bolts (6).

2.23.12 Rotate OCV lock ring to UNLOCKED position.

2.23.13 Stop vacuum pump.

2.23.14 Disconnect vacuum line from vent port tool.

2.23.15 Remove vent port tool.

2.23.16 Attach ACGLF to crane.

\section{CAUTION}

Operator shall verify two ACGLF counterweights are at 180 degrees and 000 degrees BEFORE lifting ACGLF or lid.

2.23.17 Lower ACGLF legs into lift pockets on OCA lid.

2.23.18 Verify ACGLF legs are locked. 


\section{CAUTION}

Do NOT exceed 7,500-lb load cell reading when weight of ACGLF is zeroed out. Do NOT exceed $10,000-\mathrm{lb}$ load cell reading when weight of ACGLF is included.

2.23.19 Raise OCA lid slowly to about 6 in. above top of ICV lid, or as directed by RCT.

2.23.20 IF lid does not lift off, THEN perform the following:

[A] Contact supervisor.

[B] GO TO Subsection 3.2 or Subsection 3.3, attempt to remove lid and RETURN TO Step 2.23.21.

\section{HOLD POINT}

2.23.21 RCT, survey OCA lid interior surface and ICV lid exterior surface for radiation/contamination following site-specific procedures and initial Attachment 4.

\section{SIGN-OFF}

2.23.22 Place OCA lid on storage stand.

2.23.23 Remove OCV seal test port plug.

\subsection{ICV Lid Removal}

\section{CAUTION}

Operator shall verify two ACGLF counterweights are at 180 degrees and 000 degrees BEFORE lifting ACGLF or lid.

2.24.1 Lower ACGLF legs into lifting pockets on ICV lid.

2.24.2 Verify ACGLF legs are locked.

2.24.3 Remove ICV vent port cover.

2.24.4 Remove ICV outer vent port plug.

2.24.5 Install ICV vent port tool. 
2.24.6 Connect vacuum line to vent port tool.

2.24.7 Retrieve ICV inner vent port plug into ICV vent port tool.

\section{CAUTION}

Vacuum should not exceed $15 \mathrm{in.} \mathrm{Hg}$ when attempting to open ICV.

2.24.8 Start vacuum pump and evacuate to 3 to $15 \mathrm{in}$. $\mathrm{Hg}$. vacuum gauge.

2.24.9 Record $\mathrm{T}_{\text {ICV_open }}$ on Attachment 4.

\section{SIGN-OFF}

2.24.10 Record date and time ICV was vented and verify within 24 hours of $\mathrm{T}_{\text {arrive }}$ on Attachment 10, Time and Date Data Sheet for Receipt of Content Code LA-154.

\section{SIGN-OFF}

2.24.11 Remove the following:

- ICV lock ring bolts (3)

- ICV seal test port plug

2.24.12 Rotate ICV lock ring to UNLOCKED position.

2.24.13 Stop vacuum pump.

2.24.14 Disconnect vacuum line from ICV vent port tool.

\section{HOLD POINT}

2.24.15 RCT, survey for radiation/contamination using site-specific procedures, and initial Attachment 4.

\section{SIGN-OFF}

2.24.16 Remove ICV vent port tool and ICV inner vent port plug. 


\section{WARNING}

In Step 2.24.17 the ICV body may have an inert atmosphere. Entry shall be prohibited until body has been vented.

\section{CAUTION}

Do NOT exceed 5,000-lb load cell reading when weight of ACGLF is zeroed out. Do NOT exceed $7,500-\mathrm{lb}$ load cell reading when weight of ACGLF is included.

2.24.17 Raise ICV lid slowly to clear ICV body and hold it about $2 \mathrm{ft}$ above top of ICV body flange, or as directed by RCT.

2.24.18 IF lid does not lift off ICV, THEN perform the following:

[A] Contact supervisor.

[B] GO TO Subsection 3.2 or Subsection 3.3, attempt to remove lid, and RETURN TO Step 2.24.19.

\section{HOLD POINT}

2.24.19 RCT, survey ICV lid interior surface and top of payload for radiation/contamination using site-specific procedures and initial Attachment 4.

\section{SIGN-OFF}

2.24.20 Place ICV lid on storage stand.

2.24.21 Supervisor, review/validate entries on Attachment 10 and sign.

\section{SIGN-OFF}

2.25 Unloading Payload Assembly

2.25.1 Attach appropriate legs/adaptor to ACGLF.

\section{CAUTION}

Operator shall verify two ACGLF counterweights are at 180 degrees and 000 degrees BEFORE lifting ACGLF or lid. 
2.25.3 Lock ACGLF legs into payload pallet,

OR connect lifting clips to SWB or TDOP as applicable.

2.25.4 Position ACGLF counterweights to predetermined positions as marked on top of payload.

2.25.5 Raise payload less than $1 \mathrm{ft}$ AND, if necessary, further balance payload using counterweight controls at ACGLF console until a balance of \pm 0.5 degrees is obtained on both axis.

NOTE

Perform Steps 2.25.6, 2.25.7 and 2.25.8 concurrently to remove payload.

2.25.6 Monitor ACGLF indicated balance and adjust counterweights as needed.

2.25.7 Raise payload assembly slowly.

2.25.8 Inspect payload for damage and initial Attachment 4.

SIGN-OFF

\section{HOLD POINT}

2.25.9 RCT, using site-specific procedures, survey payload assembly for radiation/contamination as it is raised, and initial Attachment 4.

\section{SIGN-OFF}

2.25.10 If payload is damaged, follow site-specific procedures.

2.25.11 Place payload assembly in designated area.

2.25.12 Supervisor, review/validate entries on Attachment 4 and sign.

\section{SIGN-OFF}

2.26 Packaging Operational Checks and Examinations

2.26.1 Record OCA serial number on Attachment 5, LANL High Wattage Empty Packaging Shipment Data Sheet.

\section{SIGN-OFF}

2.26.2 Record torque wrench serial number(s) and calibration due date(s) on Attachment 5.

\section{SIGN-OFF}

2.26.3 Verify packaging maintenance is current by checking maintenance labels next to name plate, and initial Attachment 5.

\section{SIGN-OFF}


2.26.4 RCT, IF surveys for items in Step 2.27.1, 2.28.1, or 2.29.1 were completed previously AND results were below contamination limits, THEN enter applicable data for each step on Attachment 5.

2.26.5 RCT, IF surveys were NOT completed previously, THEN GO TO applicable subsection(s) below.

- Subsection 2.27 for OCA Lid Inspection and Cleaning

- Subsection 2.28 for ICV Lid Inspection and Cleaning

- Subsection 2.29 for OCA Body Inspection and Cleaning

\section{NOTE}

Subsections 2.27 through 2.33 (and included steps) must be completed, but may be done in any order IF radiological control steps are not bypassed.

\subsection{OCA Lid Inspection and Cleaning}

2.27.1 RCT, IF survey was NOT completed previously, THEN survey OCV lid interior and exterior and record applicable data on Attachment 5.

\section{SIGN-OFF}

2.27.2 Inspect OCA lid for the following:

- Visible deformation

- Dents or abnormal flat spots $>1 / 2$ inch

- Abnormal scratches or gouges

- Obvious punctures, tears or cracks in exposed welds

- Plastic burn out plugs (3) in place and intact

- Fiberglass tubes in place

- Distortions or cracks on or around lifting attachments

- Lid lift pocket covers attached and serviceable

- Z-ring screws in place and tight

- Guide plates and screws in place and tight

2.27.3 Remove foreign material from the following:

- Lock ring flange

- Sealing surfaces

- Test port access threads

2.27.4 Verify arrow above seal test port aligns with UNLOCKED arrow on lock ring.

2.27.5 Initial Attachment 5 to document OCA lid components and hardware are satisfactory.

\section{SIGN-OFF}


2.28 ICV Lid Inspection and Cleaning

2.28.1 RCT, IF survey was NOT completed previously, THEN survey ICV lid interior and exterior and record applicable data on Attachment 5.

\section{SIGN-OFF}

2.28.2 Inspect ICV lid for the following:

- Visible deformation

- Punctures

- Abnormal scratches or gouges

- Distortions on or around lifting attachments

- Upper spacer and screws installed and tight

- Foam debris seal intact and undamaged

- Lock ring undamaged

2.28.3 Remove foreign material from the following:

- Lock ring flange

- Debris seal

- Sealing surfaces

2.28.4 Inspect ICV wiper O-ring for the following:

- Cleanliness (no visible dirt or debris)

- Damage (voids, cracks, and gouges)

2.28.5 IF O-ring is damaged, THEN GO TO WI-CH.02, replace O-ring, and RETURN TO Step 2.28.7.

2.28.6 IF O-ring is removed for cleaning,

THEN apply a light coat of vacuum grease before installing.

2.28.7 Initial Attachment 5 to document ICV lid components and hardware are satisfactory.

\section{SIGN-OFF}

2.29 OCA Body Inspection and Cleaning

2.29.1 RCT, IF survey was NOT completed previously, THEN survey OCA body exterior and ICV body interior and record applicable data on Attachment 5.

\section{SIGN-OFF}


2.29.2 Remove upper and lower main O-rings and set aside for cleaning and inspection.

2.29.3 Inspect OCA body for the following:

- Obvious punctures or tears

- Obvious cracks in exposed welds

- Dents or abnormal flat spots $>1 / 2$ inch

- Abnormal scratches or gouges

- Burn out plugs (6) in place and intact

- Forklift pocket threaded inserts (8) intact

- Lock ring threaded inserts (6) intact

- Tears or excessive wear on ceramic fiber gasket

- Lock ring stop undamaged

2.29.4 Remove foreign material from the following:

- Test port and threads

- Vent port and threads

- Lock ring flange

- Sealing surfaces

2.29.5 Initial Attachment 5 to document OCA body inspection is satisfactory.

\section{SIGN-OFF}

2.30 OCA Components Inspection and Cleaning

2.30.1 Clean and inspect the following for deformation, scratches, or burrs:

- OCV vent port cover and O-rings

- OCA vent port access plug

- OCV vent port plug and O-rings

- OCA test port access plug

- OCV test port plug and O-ring

- Lock ring bolts (6)

2.30.2 IF O-rings are damaged, THEN GO TO WI-CH.01, replace O-ring(s), and RETURN TO Step 2.30.4.

2.30.3 Apply a light coat of vacuum grease to the following:

- OCV vent port plug threads and sealing O-ring

- OCV vent port cover threads and sealing O-ring

- OCV test port plug threads and O-ring

2.30.4 Verify annulus debris shield is intact and installed. 
2.30.5 Apply a light coat of nickel bearing lubricant to the following:

- OCA lock ring bolt threads (6)

- OCV test port access plug threads

- OCA vent port access plug threads

2.30.6 Clean upper and lower main O-rings and inspect for tears, nicks, flat spots or cracks.

2.30.7 IF O-rings are damaged,

THEN GO TO WI-CH.02, replace O-ring(s), and RETURN TO Step 2.30.9.

2.30.8 Lubricate upper and lower main O-rings with a light coat of vacuum grease.

2.30.9 Install upper and lower main O-rings.

2.30.10 Initial Attachment 5 to document OCA component and hardware inspections are satisfactory.

\section{SIGN-OFF}

2.31 ICV Body Inspection and Cleaning

2.31.1 Remove upper and lower main O-rings and set aside for cleaning and inspection.

2.31.2 Vent ICV body with a standard fan for 2 to 3 minutes.

2.31.3 Remove foreign material from the following:

- Test port threads

- Vent port threads

- O-ring grooves

- Filter ports

- Sealing surfaces

- Lock ring flange

2.31.4 Inspect the following for deformation, scratches, or burrs:

- Upper and lower O-ring grooves

- Vent port threads

- Seal test port threads

- Lock ring flange

- Lower spacer installed with no tears in skin

- Lower spacer fasteners installed

2.31.5 Initial Attachment 5 to document ICV body inspection is satisfactory. 
2.32 ICV Components Inspection and Cleaning

2.32.1 Clean and inspect the following for deformation, scratches, or burrs:

- ICV vent port cover and seal

- ICV vent port outer plug and O-ring

- ICV vent port inner plug and O-ring

- ICV seal test port plug and O-ring

- ICV lock ring bolts (3)

2.32.2 IF O-rings are damaged, THEN GO TO WI-CH.01, replace O-ring(s), and RETURN TO Step 2.32.4.

2.32.3 Apply a light coat of vacuum grease to the following:

- ICV vent port cover threads (and O-ring if installed)

- ICV outer vent port plug threads and O-ring

- ICV inner vent port plug threads and O-ring

- ICV seal test port plug threads and O-ring

2.32.4 Apply a light coat of nickel bearing lubricant to threads of ICV lock ring bolts (3).

2.32.5 Clean and inspect upper and lower main O-rings for tears, nicks, flat spots, or cracks.

2.32.6 IF O-rings are damaged,

THEN GO TO WI-CH.02, replace O-ring(s), and RETURN TO Step 2.32.9.

2.32.7 Lubricate upper and lower main O-rings with a light coat of vacuum grease.

2.32.8 Install upper and lower main O-rings.

2.32.9 Initial Attachment 5 to document ICV components and hardware inspections are satisfactory.

\section{SIGN-OFF}

\subsection{ICV Cavity Inspection}

2.33.1 Check ICV cavity for water by visually inspecting the absorbent material inserted into the hole in the lower spacer assembly. 


\begin{tabular}{|lll}
\hline DOE/WIPP 02-3220 & Rev. 1 & Page 48 of 96 \\
\hline
\end{tabular}

\section{NOTE}

Disposal of absorbent material and water will be at direction of the RCT.

2.33.2 IF water is found in ICV, THEN perform ONE of the following, if possible:

- Remove water using wet/dry vacuum

- Remove using absorbent material attached to end of rod

2.33.3 IF water is inside ICV, THEN, GO TO Subsection 3.1, perform steps, and RETURN TO Step 2.33.4.

2.33.4 Initial Attachment 5 to document ICV is free of water.

\section{SIGN-OFF}

2.33.5 Verify all preshipment inspections are complete and initial Attachment 5.

\section{SIGN-OFF}

2.34 ICV Lid Installation

2.34.1 Match ICV lid and body serial numbers.

2.34.2 Record ICV serial number on Attachment 5.

\section{SIGN-OFF}

2.34.3 Attach ACGLF to crane.

\section{CAUTION}

Operator shall verify two ACGLF counterweights are at 180 degrees and 000 degrees BEFORE lifting ACGLF or lid.

2.34.4 Lower ACGLF legs into lifting pockets on ICV lid.

2.34.5 Verify ACGLF legs are locked.

2.34.6 Align UNLOCKED arrows and install ICV lid onto ICV body using crane and ACGLF.

2.34.7 Install ICV vent port tool into ICV vent port. 


$\begin{array}{lll}\text { DOE/WIPP 02-3220 } & \text { Rev. } 1 & \text { Page } 49 \text { of } 96\end{array}$

2.34.8 Connect vacuum line to ICV vent port tool.

2.34.9 Start vacuum pump and evacuate to 3 to $15 \mathrm{in}$. $\mathrm{Hg}$. vacuum gauge.

2.34.10 Rotate ICV lock ring to LOCKED position.

2.34.11 Stop vacuum pump.

2.34.12 Disconnect vacuum line from vent port tool.

2.34.13 Remove ICV vent port tool.

2.34.14 Vent ICV to atmosphere.

2.34.15 Install ICV inner vent port plug.

2.34.16 Torque ICV inner vent port plug to 55 to $65 \mathrm{lb}$-in and initial Attachment 5.

\section{SIGN-OFF}

2.34.17 Install ICV outer vent port plug.

2.34.18 Torque ICV outer vent port plug to 55 to $65 \mathrm{lb}$-in and initial Attachment 5.

\section{SIGN-OFF}

2.34.19 Install ICV seal test port plug.

2.34.20 Torque ICV seal test port plug to 55 to $65 \mathrm{lb}$-in and initial Attachment 5.

\section{SIGN-OFF}

2.34.21 Install ICV vent port cover.

2.34.22 Torque ICV vent port cover to 55 to $65 \mathrm{lb}$-in and initial Attachment 5 .

\section{SIGN-OFF}

2.34.23 Install ICV locking ring bolts (3).

2.34.24 Torque each ICV locking ring bolt to 28 to $32 \mathrm{lb}$-ft and initial Attachment 5. 


\subsection{OCA Lid Installation}

2.35.1 Match OCA lid and body serial numbers.

2.35.2 Record OCA serial number on Attachment 5.

\section{SIGN-OFF}

2.35.3 Install OCV seal test port plug.

2.35.4 Torque OCV seal test port plug to 55 to $65 \mathrm{lb}$-in and initial Attachment 5.

\section{SIGN-OFF}

\section{CAUTION}

Operator shall verify two ACGLF counterweights are at 180 degrees and 000 degrees BEFORE lifting ACGLF or lid.

2.35.5 Lower ACGLF legs into lifting pockets on OCA lid using crane.

2.35.6 Verify ACGLF legs are locked.

2.35.7 Install OCA lid onto OCA body.

2.35.8 Install OCV vent port tool into OCV vent port.

2.35.9 Connect vacuum line to OCV vent port tool.

2.35.10 Start vacuum pump and evacuate to 3 to $15 \mathrm{in}$. $\mathrm{Hg}$. vacuum gauge.

2.35.11 Rotate OCV lock ring to LOCKED position.

2.35.12 Stop vacuum pump.

2.35.13 Disconnect vacuum line from vent port tool.

2.35.14 Remove OCV vent port tool.

2.35.15 Vent OCV to atmosphere.

2.35.16 Install OCV vent port plug. 


$\begin{array}{lll}\text { DOE/WIPP 02-3220 } & \text { Rev. } 1 & \text { Page } 51 \text { of } 96\end{array}$

2.35.17 Torque OCV vent port plug to 55 to $65 \mathrm{lb}$-in and initial Attachment 5 .

\section{SIGN-OFF}

2.35.18 Install OCV vent port cover.

2.35.19 Torque OCV vent port cover to 55 to $65 \mathrm{lb}$-in and initial Attachment 5 .

\section{SIGN-OFF}

2.35.20 Install OCA seal test port thermal plug and access plug.

2.35.21 Torque OCA seal test port access plug to 35 to $45 \mathrm{lb}$-ft and initial Attachment 5.

\section{SIGN-OFF}

2.35.22 Install OCA vent port thermal plug and access plug.

2.35.23 Torque OCA vent port access plug to 35 to $45 \mathrm{lb}$-ft and initial Attachment 5.

\section{SIGN-OFF}

2.35.24 Install OCA lock ring bolts (6).

2.35.25 Torque each OCA lock ring bolt to 28 to $32 \mathrm{lb}-\mathrm{ft}$ and initial Attachment 5.

\section{SIGN-OFF}

2.35.26 Install OCA lid lift pocket covers.

2.35.27 Verify preshipment preparations are complete and unit is ready for transport, and initial Attachment 5.

\section{SIGN-OFF}

2.35.28 Supervisor, review/validate entries on Attachment 5 and sign.

\section{SIGN-OFF}


2.36 Installation of Packaging on Transport Trailer

\section{NOTE}

When loading packages on trailer, or loading payload into packaging that is already on trailer, the following applies:

- Packages having a gross weight difference (heaviest to lightest) of $2,000 \mathrm{lb}$ or less can be considered equal and do not require a specific sequence for positioning on the trailer.

- Packages having a gross weight difference (heaviest to lightest), greater than 2,000 pounds shall be positioned on the trailer as follows:

\begin{tabular}{|l|l|l|l|l|}
\hline \multirow{4}{*}{$\begin{array}{l}\text { TRAILER } \\
\text { FRONT }\end{array}$} & *1. Heaviest & Medium & Lighter & \\
\cline { 2 - 4 } & 2. Heaviest & Lighter & Medium & \\
\cline { 2 - 4 } & *3. Heaviest & Lighter & None & REARER \\
\cline { 2 - 4 } & 4. Lighter & Heaviest & None & \\
\cline { 2 - 4 } & 5. Heaviest & None & None & \\
\hline \multirow{2}{*}{ * Preferred method }
\end{tabular}

2.36.1 Record the following on Attachment 6, LANL High Wattage Trailer Data Sheet:

- Shipment number

- Trailer number

- Packaging number(s)

\section{SIGN-OFF}

2.36.2 Verify trailer inspection is current.

2.36.3 Record trailer inspection date on Attachment 6 .

\section{SIGN-OFF}

2.36.4 Inspect tie-downs for the following:

- Damage

- Defects 
2.36.5 IF TRUPACT-II was removed for unloading operations, THEN perform the following:

[A] Position transport trailer in designated area.

[B] Lower trailer jacks (landing gear) ensuring trailer is level.

[C] Install wheel chocks.

[D] Install jack stands on freestanding trailers.

\section{CAUTION}

Forklift tip-back beyond level may damage package exterior surface.

[E] Transport packaging to transport trailer.

[F] Load packaging designated for position \#1 onto trailer with vent port on driver side of trailer.

[G] If applicable, load packaging designated for position \#2 onto trailer with vent port on driver side of trailer.

[H] If applicable, load packaging designated for position \#3 onto trailer with vent port on driver side of trailer.

[l] Install four tie-down assemblies for each packaging loaded on trailer.

[J] Install packaging forklift pocket access covers.

2.36.6 Record packaging serial number(s) and weights on Attachment 6 .

\section{SIGN-OFF}

2.36.7 Record total weight of all loaded packaging as payload weight on Attachment 6.

\section{SIGN-OFF}

2.36.8 Verify shipment complies with 49 CFR Part 172 , Subpart D, Subpart E, and Subpart F and initial Attachment 6.

\section{SIGN-OFF}


2.36.9 Complete information transfer to shipping documents as required for the specific shipment.

2.36.10 Verify shipping papers comply with 49 CFR Part 172 , Subpart C, and initial Attachment 6.

\section{SIGN-OFF}

2.36.11 Initial for trailer loading complete on Attachment 6 .

\section{SIGN-OFF}

2.36.12 Supervisor, review/validate entries on Attachment 6 and sign. 
Figure 2.1 - Evacuation/Nitrogen Backfill

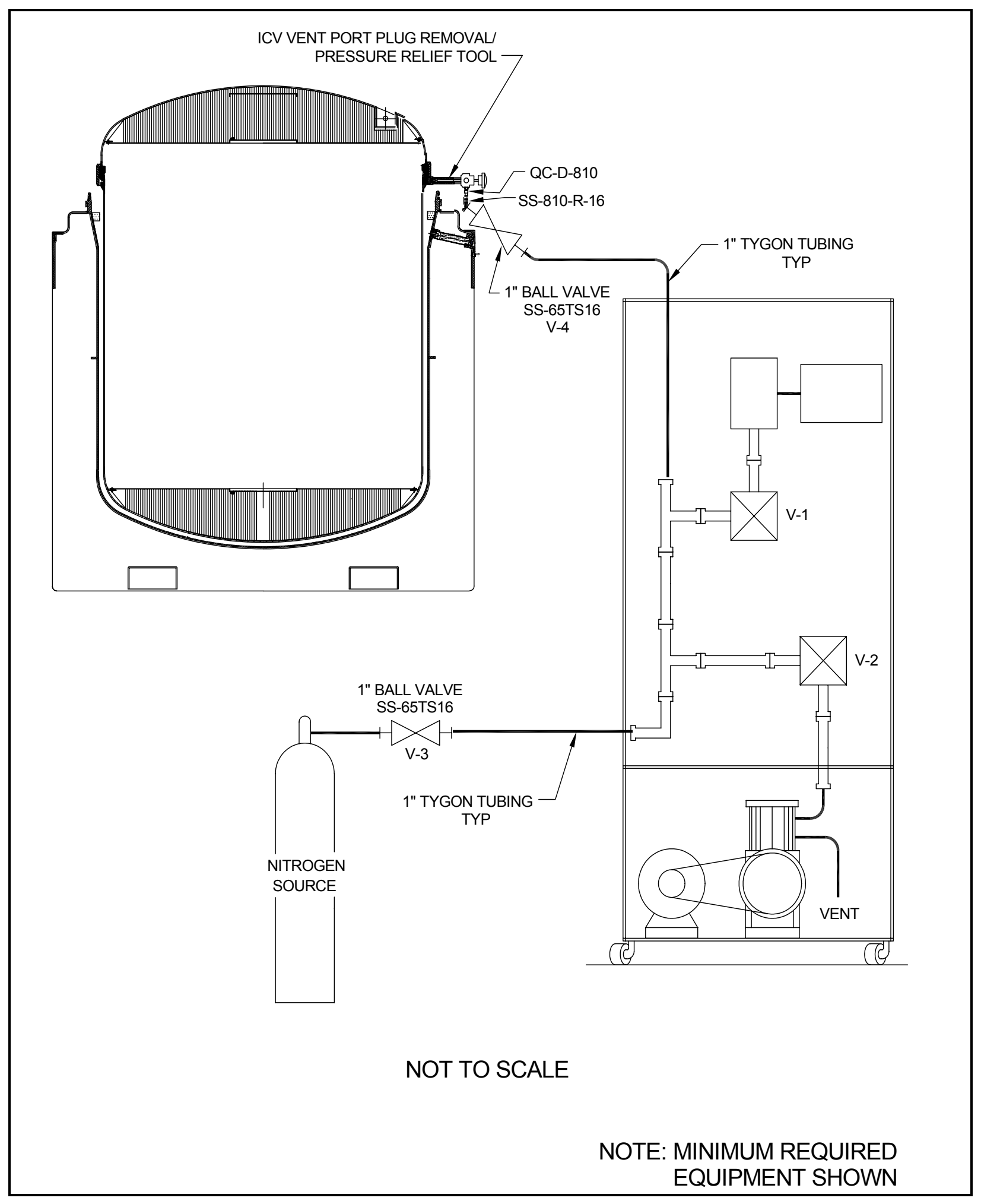




\subsection{ABNORMAL OPERATIONS}

3.1 Empty ICV Assembly Removal - (if water found in ICV or annual maintenance only)

3.1.1 Verify ICV lid is installed and locked.

3.1.2 Attach crane to ACGLF.

\section{CAUTION}

Operator shall verify two ACGLF counterweights are at 180 degrees and 000 degrees respectively.

3.1.3 Lower ACGLF legs into lifting pockets of ICV lid.

3.1.4 Verify ACGLF legs are locked.

3.1.5 If annulus foam ring is present, remove and set aside for later use.

3.1.6 Remove empty ICV assembly from OCV body using crane and ACGLF.

\section{NOTE}

If required by site-specific policy, RCT shall survey OCV interior for radiation/contamination BEFORE initiating OCV inspection process.

3.1.7 Check visually for presence of water in bottom of OCV.

3.1.8 If freestanding water is NOT observed in bottom of OCV body, GO TO Step 3.1.12.

\section{CAUTION}

Operator shall don protective clothing and equipment in accordance with site safety manual before entering OCV cavity. Operator also shall use precautions when entering OCV cavity to preclude damage to OCV body sealing flange.

3.1.9 Use wet/dry vacuum and/or absorbent materials to remove freestanding water. 


$\begin{array}{lll}\text { DOE/WIPP 02-3220 } & \text { Rev. } 1 & \text { Page } 57 \text { of } 96\end{array}$

\section{NOTE}

Cleaning and waste materials shall be managed according to site waste management procedures.

3.1.10 Remove equipment and exit OCV cavity using precautions not to damage OCV body sealing flange.

3.1.11 Verify OCV is free of standing water.

\section{CAUTION}

Operator shall verify two ACGLF counterweights are at 180 degrees and 000 degrees respectively.

\section{NOTE}

When Step 3.1.12 is complete, ICV vent port should be within $1 \mathrm{ft}$ on either side of OCV vent port.

3.1.12 Reinstall ICV assembly into OCV body using crane and ACGLF.

3.1.13 If annulus foam ring was removed in Step 3.1.5, reinstall annulus foam ring.

\subsection{Using Heat Guns}

3.2.1 Using heat guns, heat ICV or OCV lid O-rings (as necessary) for up to 1 hour. 


\section{CAUTION}

Operator shall verify two ACGLF counterweights are at 180 degrees and 000 degrees respectively.

\section{CAUTION}

When lifting ICV lid, do NOT exceed 5,000-lb load cell reading when weight of ACGLF is zeroed out. Do NOT exceed 7,500-lb load cell reading when weight of ACGLF is included.

\section{CAUTION}

When lifting OCA lid, do NOT exceed 7,500-lb load cell reading when weight of ACGLF is zeroed out. Do NOT exceed $10,000-\mathrm{lb}$ load cell reading when weight of ACGLF is included.

3.2.2 Attempt to raise lid using the slowest possible speed.

3.2.3 Raise lid as directed by RCT and RETURN TO normal operations.

\subsection{Pressurizing with Nitrogen or Compressed Air}

3.3.1 Obtain the following:

- Nitrogen bottle with $\geq 500 \mathrm{lb}$ pressure or other air source capable of being regulated in $1 \mathrm{psi}$ increments

- Pressure assembly (see Figure 3.1, Flow Diagram for Nitrogen Bottle/Compressed Air ICV/OCA Lid Pressurization, for example of a pressure assembly)

- If not already installed, ICV/OCV vent port tools, as applicable

3.3.2 Perform the following for compressed air or nitrogen:

[A] Assemble pressure assembly (see Figure 3.1).

[B] If not already installed, install vent port tool hand tight.

[C] Connect pressure assembly to quick disconnect on vent port tool. 


$\begin{array}{lll}\text { DOE/WIPP 02-3220 Rev. } 1 & \text { Page } 59 \text { of } 96\end{array}$

[D] Close valve V-1.

[E] Close valve V-2.

[F] Verify supply valve is closed.

[G] Verify back pressure relief valve is fully backed off.

$[H]$ Verify pressure regulator is fully backed off.

[l] Connect supply line and regulator to nitrogen bottle or compressed air source.

[J] Open supply valve and adjust $\mathrm{N}_{2}$ or air supply regulator to a maximum of 150 psig.

[K] Adjust R1 to 2.1 psig.

[L] Adjust R2 until it begins to relieve pressure.

[M] Adjust R1 to fully backed off.

[N] Bleed briefly through $\mathrm{V}-1$.

[O] Adjust R1 to 1 psig.

3.3.3 Verify counterweights are at 180 degrees and 000 degrees. 


$\begin{array}{lll}\text { DOE/WIPP 02-3220 Rev. } 1 & \text { Page } 60 \text { of } 96\end{array}$

\section{WARNING}

To avoid personnel injury, ICV or OCV should not be pressurized above 2 psi. Do NOT pressurize a loaded ICV unless precautions are taken to prevent possible contamination when lid is raised.

\section{CAUTION}

When lifting ICV lid, do NOT exceed 5,000-lb load cell reading when weight of ACGLF is zeroed out. Do NOT exceed 7,500-lb load cell reading when weight of ACGLF is included.

\section{CAUTION}

When lifting OCA lid, do NOT exceed 7,500-lb load cell reading when weight of ACGLF is zeroed out. Do NOT exceed $10,000-\mathrm{lb}$ load cell reading when weight of ACGLF is included.

3.3.4 Attempt to lift lid using crane at the slowest rate possible while monitoring load cell.

3.3.5 Perform the following while attempting to lift lid with crane:

[A] Throttle valve $\mathrm{V}-2$, keeping pressure $\leq 2 \mathrm{psi}$.

[B] When lid loosens, close V-2.

[C] Close supply valve.

[D] Open V-1 to depressurize assembly.

[E] Disconnect supply line from pressure assembly.

[F] Disconnect pressure assembly from vent port tool.

[G] Disconnect vent port tool and survey tool if applicable.

[H] Disconnect supply line and regulator from nitrogen bottle or compressed air source. 
3.3.6 Raise lid as directed by RCT AND continue with normal operations.

3.3.7 IF after pressurizing to 2 psi lid still does not lift, THEN contact WIPP M\&O Contractor CH Packaging Maintenance Engineer.

\subsection{Venting}

\section{NOTE}

If a sealed package cannot be shipped within the time set forth in the TRUPACT-II SAR, the package must be vented.

3.4.1 If venting is required, GO TO the applicable subsection below, perform task, and RETURN TO Step 3.4.2:

- Subsection 2.23 for OCA lid removal

- Subsection 2.24 for ICV lid removal

3.4.2 Wait three minutes.

3.4.3 If reinstalling lids $\mathbf{G O}$ TO the applicable subsection below, perform steps, RETURN TO Subsection 2.20, Installation of Package onto Transport Trailer, and continue processing:

- Subsection 2.17 for ICV lid installation

- Subsection 2.18 for nitrogen backfill

- Subsection 2.19 for OCA lid installation 
Figure 3.1. Flow Diagram for Nitrogen Bottle/Compressed Air ICV/OCA Lid Pressurization

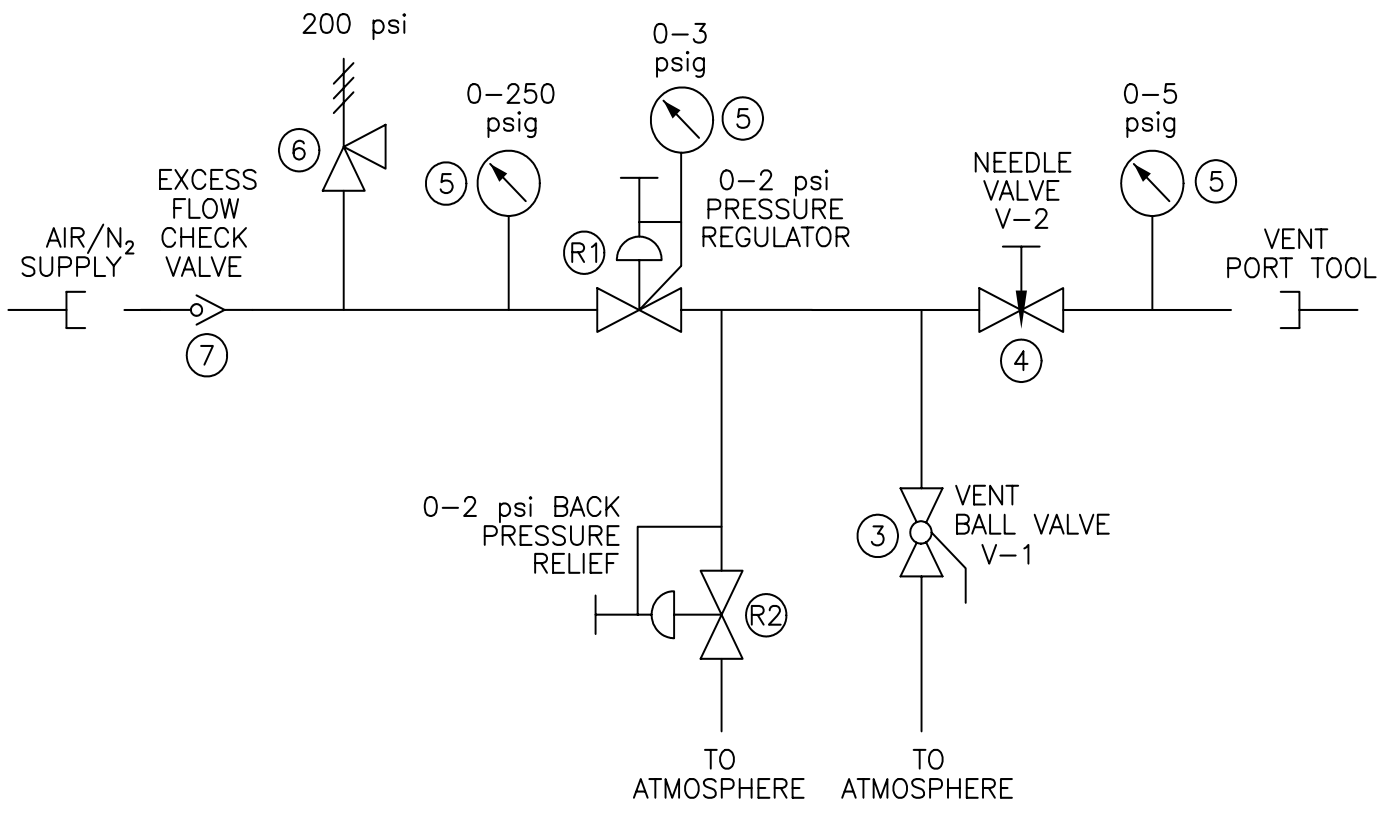

\begin{tabular}{|c|c|}
\hline ITEM \# & DESCRIPTION \\
\hline (R1) & $\begin{array}{l}0-3 \text { psi PRESSURE REGULATOR } \\
\text { TO ATMOSPHERE } \\
\text { (RATED FOR } 250 \text { psi INPUT MINIMUM) }\end{array}$ \\
\hline (R2) & $\begin{array}{l}\text { 0-2 psi BACK PRESSURE RELIEF } \\
\text { TO PROCESS PRESSURE } \\
\text { (RATED FOR } 250 \text { psi INPUT MINIMUM } \\
\text { WITH A THREADED REF. PORT) }\end{array}$ \\
\hline (3) & 3/8" BALL VALVE \\
\hline (4) & 3/8" NEEDLE VALVE \\
\hline (5) & PRESSURE GAGE \\
\hline (6) & 3/8" PRESSURE RELIEF VALVE \\
\hline (7) & 1/4" EXCESS FLOW CHECK VALVE \\
\hline AR & $3 / 8 "$ TUBING \\
\hline AR & PIPE/TUBING, ADAPTERS \& FITTINGS \\
\hline
\end{tabular}




\subsection{PRESHIPMENT LEAKAGE RATE TESTING}

\subsection{Basic Information}

4.1.1 Introduction - This section of the document provides instructions for performing ICV and OCV preshipment leakage rate tests on the following packaging seals, using a nondestructive helium $(\mathrm{He})$ leak test:

- ICV upper main O-ring seal

- ICV outer vent port plug O-ring seal

- OCV upper main O-ring seal

- OCV vent port plug O-ring seal

\subsubsection{References}

- U.S. Department of Energy, Safety Analysis Report for the TRUPACT-II Shipping Package

- $\quad$ TRUPACT-II Certificate of Compliance No. 9218

- DOE/WIPP 02-3183, CH Packaging Program Guidance

- DOE/WIPP 02-3185, CH Packaging Maintenance Manual

- ANSI N 14.5, 1997, Radioactive Materials Leakage Tests on Packages for Shipment

- ASNT, Recommended Practice No. SNT-TC-1A, June 1980

- WP 13-RP.01, Test Report for WP 13-QA1082 Procedure Qualification

\subsubsection{Equipment}

\section{MEASURING AND TEST EQUIPMENT}

- Varian 938-41 or 959 Helium Leak Detector with 7 to $14 \mathrm{cfm}$ mechanical vacuum pump

- Roughing pump

- Helium leak standard for calibrating leak detector

- Pressure/vacuum gauge, $30 \mathrm{in}$. $\mathrm{Hg}$ to $30 \mathrm{psig}$

- Temperature measuring device, $32^{\circ} \mathrm{F}$ to $120^{\circ} \mathrm{F}\left(0^{\circ} \mathrm{C}\right.$ to $\left.50^{\circ} \mathrm{C}\right)$

- Ambient atmospheric pressure measuring device 
- Watch or stopwatch, digital or sweep second hand (no calibration required)

- Torque wrench with 55 to $65 \mathrm{lb}$-in range

- Torque wrench with 30 to $50 \mathrm{lb}-\mathrm{ft}$ range

SPECIAL TEST EQUIPMENT

- ICV/OCV vent port plug removal/pressure relief tools

- ICV/OCV seal leak check tools

- ICV/OCV leak detection tools

- Miscellaneous hardware and test connections

- ICV/OCV vent port plug/cover removal and installation tools

CONSUMABLE MATERIALS

- Welding grade helium (with certificate of conformance)

- Argon or nitrogen (purge gas)

\subsubsection{Precautions and Limitations}

- The following leak test procedure may be used, or each user may develop and qualify a procedure in accordance with the guidelines of ANSI N14.5, 1997. Sites that opt to qualify their own leak test procedure must submit the procedure qualification record and procedure to the WIPP M\&O CH Packaging Maintenance Engineer for approval.

- Leak testing of $\mathrm{CH}$ packaging shall be performed by personnel qualified in accordance with the American Society for Nondestructive Testing Practice No. SNT-TC-1A, June 1980 edition and supplement.

- This procedure is qualified per WP 13-RP.01, Test Report for WP 13-QA1082 Procedure Qualification for the Varian 938-41 and 959 MSLD, and test line configuration defined in that report. $\mathrm{CH}$ packaging users adopting this leak test must not deviate from the test configuration(s) used to qualify the procedure.

- The helium leak detector shall be calibrated to a minimum sensitivity of $1.3 \times 10^{-7}$ standard cubic centimeters per second (scc/s) He.

- The leakage rate acceptance criteria of $\leq 1.0 \times 10^{-7} \mathrm{scc} / \mathrm{s}$ of air equates to a leakage rate of $\leq 2.6 \times 10^{-7} \mathrm{scc} / \mathrm{s} \mathrm{He}$. The He leakage rate is only valid for a component of $\geq 4.4^{\circ} \mathrm{C}$. The acceptable He leakage rate increases with temperature, but as a conservative measure, an acceptance criteria of $\leq 2.6 \times 10^{-7} \mathrm{scc} / \mathrm{s}$ He will be used. 


\subsubsection{Prerequisite Actions}

- Verify air flow through leak check and leak detection tools.

- Verify packaging surface is free of contaminants that might mask a leak. Interior and exterior surfaces shall be dry.

\subsection{ICV Upper Main O-Ring Seal}

4.2.1 Record the following on Attachment 7, ICV Preshipment LeakageRate Test Data Sheet:

- ICV body serial number $(\mathrm{S} / \mathrm{N})$

- ICV lid S/N

- Date of leak test

- Helium leak detector $\mathrm{S} / \mathrm{N}$ and model

- Pressure/vacuum gauge $S / N$ and calibration due date

- Thermometer $\mathrm{S} / \mathrm{N}$ and calibration due date

- Torque wrench S/Ns and calibration due dates

- Standard leak $\mathrm{S} / \mathrm{N}$ and calibration due date

- Barometer $\mathrm{S} / \mathrm{N}$ and calibration due date

- Helium source connected to backfill system

\section{SIGN-OFF}

\section{NOTE}

Steps 4.2.15 through 4.2.19 may be performed in parallel with Steps 4.2.2 through 4.2.14.

4.2.2 Measure ICV surface temperature.

4.2.3 If temperature is less than $4.4^{\circ} \mathrm{C}$, stop test until surface temperature $\geq 4.4^{\circ} \mathrm{C}$.

4.2.4 Record surface temperature on Attachment 7.

\section{SIGN-OFF}

4.2.5 Verify outer vent port plug is retracted into ICV vent port plug removal/pressure relief tool.

4.2.6 Install ICV vent port tool into ICV vent port.

4.2.7 Attach vacuum pump assembly and He gas supply to vent port tool (see Figure 4.1, ICV Main O-Ring Seal Test).

4.2.8 Open isolation valve to vacuum pump. 
4.2.9 Start vacuum pump.

4.2.10 Record ambient atmospheric pressure (Patm) on Attachment 7.

\section{SIGN-OFF}

4.2.11 Evacuate ICV vent port cavity to $90 \%$ vacuum (90\% of atmospheric pressure) or better, THEN close isolation valve AND stop vacuum pump.

4.2.12 Record vacuum reading (V1) on Attachment 7.

\section{SIGN-OFF}

4.2.13 Calculate He concentration correction factor (CCF) as follows:

$$
\mathrm{CCF}=\frac{\mathrm{Patm}}{\mathrm{V} 1}
$$

\subsubsection{Record CCF on Attachment 7.}

\section{SIGN-OFF}

4.2.15 Perform pretest calibration of leak detector (to the temperaturecorrected standard leak value) and record results on Attachment 7.

\section{SIGN-OFF}

4.2.16 Install ICV seal leak check tool in ICV seal test port.

4.2.17 Connect leak detector to ICV leak check tool (see Figure 4.1).

4.2.18 Verify isolation valve open.

4.2.19 Evacuate space between O-ring seals through ICV seal test port.

\section{NOTE}

To measure $\mathrm{a} \leq 2.6 \times 10^{-7} \mathrm{scc} / \mathrm{s}$ He leakage rate, indicated He background will be allowed to stabilize at $2.6 \times 10^{-7} \mathrm{scc} / \mathrm{s}$ He or less and remain below the limit for a minimum of 3 minutes.

4.2.20 Record He background (RB) on Attachment 7.

\section{SIGN-OFF}

4.2.21 Open $\mathrm{He}$ valve and backfill cavity with $\mathrm{He}$ to a pressure slightly greater than atmospheric pressure (+1 psi, $-0 \mathrm{psi})$.

4.2.22 Close He valve. 
4.2.23 Record backfill pressure reading on Attachment 7 .

\section{SIGN-OFF}

4.2.24 Begin timing for 3-minute dwell time.

4.2.25 Monitor pressure gauge and add $\mathrm{He}$ as required to maintain $\mathrm{He}$ atmosphere in the cavity.

\section{NOTE}

A dwell time of 3 minutes will be used to determine leakage rate of ICV upper main O-ring seal.

4.2.26 Record measured leakage rate (RT) after 3-minute dwell time on Attachment 7.

\section{SIGN-OFF}

\section{NOTE}

Steps 4.3.1 through 4.3.6 may be performed in parallel with Steps 4.2.27 through 4.2.35.

4.2.27 Remove test assembly from leak detector.

4.2.28 Install calibrated leak to leak detector.

4.2.29 Perform post-test calibration of leak detector and record results on Attachment 7.

\section{SIGN-OFF}

\section{NOTE}

If background reading (RB) is larger than the leak rate reading (RT), then the background reading will not be subtracted from the leak rate reading and this (RT) becomes the actual leakage rate reading.

4.2.30 Calculate the ICV Upper Main O-Ring Seal leakage rate using the applicable condition below and record on Attachment 7:

[A] If there is NO difference in the post-test calibration from the pretest calibration, use the following equation: subtract the $\mathrm{He}$ background at the start of test (RB) from the He background at end of test (RT). The leakage rate is (RT - RB) $x$ CCF. This equals the leakage rate for this segment of the test.

[B] If post-test calibration is LESS than pretest calibration, use the following calculation: (RT + calibration difference - RB) x CCF. This equals the leakage rate for this segment of the test under this condition of recalibration. 
[C] If post-test calibration is MORE than pretest calibration, use the following calculation: (RT - calibration difference - RB) x CCF. This equals the leakage rate for this segment of the test under this condition of recalibration.

\section{SIGN-OFF}

4.2.31 If the acceptance criterion is satisfied $\left(\leq 2.6 \times 10^{-7} \mathrm{scc} / \mathrm{s}\right.$ of $\left.\mathrm{He}\right)$, this segment of the test procedure is complete.

\section{NOTE}

Leakage rate acceptance criterion is $\leq 2.6 \times 10^{-7} \mathrm{scc} / \mathrm{s} \mathrm{He}$.

4.2.32 IF ICV upper main O-ring seal leakage rate is $>2.6 \times 10^{-7} \mathrm{scc} / \mathrm{s} \mathrm{He}$, THEN perform the following:

[A] Isolate leak path.

[B] GO TO WI-CH.02, replace O-ring seal(s) and/or repair seal surface(s) per WI-CH.12, Minor Repair of ICV/OCV Seal Area Surface Finish and Vessel, and repeat leak test.

[C] If after repeated testing it is clear the seal cannot pass the test, prepare nonconformance report (NCR) and record on Attachment 7.

\section{SIGN-OFF}

4.2.33 Remove ICV seal leak check tool and associated leak test equipment from ICV seal test port.

4.2.34 Install ICV seal test port plug.

4.2.35 Torque ICV seal test port plug to 55 to $65 \mathrm{lb}$-in and initial Attachment 7.

\section{SIGN-OFF}

\subsection{ICV Outer Vent Port Plug O-Ring Seal}

\section{NOTE}

The following test should be performed immediately after Subsection 4.2, ICV Upper Main O-Ring Seal, while He atmosphere is still present in ICV vent port cavity and to minimize He saturation of O-rings before test completion.

4.3.1 Disconnect vacuum pump assembly and He supply from ICV vent port tool.

4.3.2 Install ICV outer vent port plug. 
4.3.3 Remove vent port tool.

4.3.4 Torque ICV outer vent port plug to 55 to $65 \mathrm{lb}$-in and initial Attachment 7.

\section{SIGN-OFF}

4.3.5 Purge vent port to flush out residual helium.

4.3.6 Install a clean (helium-free) ICV leak detection tool in ICV vent port.

\section{NOTE}

If Step 4.3.7 begins within 1 hour of completing ICV upper main O-ring seal leak test, THEN pretest calibration is not required. Post-test calibration result can be used for the ICV outer vent port plug O-ring seal pretest calibration.

4.3.7 Perform pretest calibration of leak detector (to the temperaturecorrected standard leak value).

4.3.8 Record pretest calibration results on Attachment 7.

\section{SIGN-OFF}

4.3.9 Connect leak detector to ICV leak detection tool (see Figure 4.2, ICV Outer Vent Port Plug O-Ring Seal Test).

4.3.10 Verify isolation valve is OPEN.

4.3.11 Evacuate ICV leak detection tool.

\section{NOTE}

To measure $\mathrm{a} \leq 2.6 \times 10^{-7} \mathrm{scc} / \mathrm{s}$ He leakage rate with a He atmosphere already present, indicated He background will be $\leq 2.6 \times 10^{-7} \mathrm{scc} / \mathrm{s} \mathrm{He}$ BEFORE the start of the dwell time.

Dwell time for ICV vent port plug O-ring seal test is 3 minutes. An initial indication does NOT necessarily indicate a leak. Residual He may still be detected.

4.3.12 Record measured leakage rate (RT) after 3 minute dwell time on Attachment 7.

\section{SIGN-OFF}

4.3.13 Remove test assembly from leak detector.

4.3.14 Install calibrated leak to leak detector. 
4.3.15 Perform post-test calibration of leak detector and record results on Attachment 7.

\section{SIGN-OFF}

4.3.16 Calculate ICV vent port plug O-ring seal leakage rate by using the applicable condition below and record on Attachment 7:

[A] If there is NO difference in the post-test calibration from the pretest calibration, the He background at end of test (RT) x CCF equals the leakage rate for this segment of the test.

[B] If post-test calibration is LESS than pretest calibration, use the following calculation: (RT + calibration difference) $\times$ CCF. This equals the leakage rate for this segment of the test under this condition of recalibration.

[C] If post-test calibration is MORE than pretest calibration, use the following calculation: (RT - calibration difference) $x$ CCF. This equals the leakage rate for this segment of the test under this condition of recalibration.

\section{SIGN-OFF}

4.3.17 If the acceptance criterion is satisfied $\left(\leq 2.6 \times 10^{-7} \mathrm{scc} / \mathrm{s}\right.$ of $\left.\mathrm{He}\right)$, this segment of the test procedure is complete.

\section{NOTE}

Leakage rate acceptance criterion is $\leq 2.6 \times 10^{-7} \mathrm{scc} / \mathrm{s} \mathrm{He}$.

4.3.18 IF ICV outer vent port plug O-ring seal leakage rate is

$>2.6 \times 10^{-7} \mathrm{scc} / \mathrm{s} \mathrm{He}$,

THEN perform the following:

[A] Isolate leak path.

[B] GO TO WI-CH.01, replace O-ring seal(s) and/or repair seal surface(s) per WI-CH.12, and repeat leak test.

[C] If after repeated testing it is clear the seal cannot pass test, prepare NCR and record on Attachment 7.

\section{SIGN-OFF}

4.3.19 Remove ICV leak detection tool from ICV vent port.

4.3.20 Install ICV vent port cover.

4.3.21 Torque ICV vent port cover to 55 to $65 \mathrm{lb}$-in and initial Attachment 7 . 


\subsubsection{GO TO Subsection 2.19.}

\subsection{OCV Upper Main O-Ring Seal}

4.4.1 Record the following on Attachment 8, OCV Preshipment Leakage Rate Test Data Sheet:

- OCV body S/N

- OCV lid S/N

- Date of leak test

- Helium leak detector $\mathrm{S} / \mathrm{N}$ and model

- Pressure/vacuum gauge $\mathrm{S} / \mathrm{N}$ and calibration due date

- Thermometer $\mathrm{S} / \mathrm{N}$ and calibration due date

- Torque wrench S/Ns and calibration due dates

- Standard leak S/N and calibration due date

- Barometer $\mathrm{S} / \mathrm{N}$ and calibration due date

- Helium source connected to backfill system

\section{SIGN-OFF}

\section{NOTE}

Steps 4.4.12 through 4.4.17 may be performed in parallel with Steps 4.4.2 through 4.4.11.

4.4.2 Measure OCV surface temperature and record on Attachment 8.

\section{SIGN-OFF}

4.4.3 If temperature is less than $4.4^{\circ} \mathrm{C}$, stop test until surface temperature $\geq 4.4^{\circ} \mathrm{C}$.

4.4.4 Attach vacuum pump assembly and He gas supply to vent port tool (see Figure 4.3, OCV Main O-Ring Seal Test).

4.4.5 Open isolation valve to vacuum pump.

4.4.6 Start vacuum pump.

4.4.7 Record ambient atmospheric pressure (Patm) on Attachment 8.

\section{SIGN-OFF}

4.4.8 Evacuate OCV cavity to $90 \%$ vacuum ( $90 \%$ of atmospheric pressure) or better, THEN close isolation valve AND stop vacuum pump.

4.4.9 Record vacuum reading $\mathrm{V} 1$ on Attachment 8.

\section{SIGN-OFF}


4.4.10 Calculate He concentration correction factor as follows:

$$
\mathrm{CCF}=\underset{\mathrm{V} 1}{\text { Patm }}
$$

\subsubsection{Record CCF on Attachment 8.}

\section{SIGN-OFF}

4.4.12 Perform pretest calibration of leak detector (to the temperaturecorrected standard leak value).

4.4.13 Record pretest calibration results on Attachment 8.

\section{SIGN-OFF}

4.4.14 Install OCV seal leak check tool in OCV seal test port.

4.4.15 Connect leak detector to OCV leak check tool (see Figure 4.3).

4.4.16 Verify isolation valve open.

4.4.17 Evacuate space between O-ring seals through OCV seal test port.

\section{NOTE}

To measure a $2.6 \times 10^{-7} \mathrm{scc} / \mathrm{s}$ He leakage rate, indicated He background will be allowed to stabilize at $\leq 2.6 \times 10^{-7} \mathrm{scc} / \mathrm{s} \mathrm{He}$ and remain below the limit for a minimum of 3 minutes.

4.4.18 Record He background (RB) on Attachment 8.

\section{SIGN-OFF}

4.4.19 Open He valve and backfill OCV cavity with He to a pressure slightly greater than atmospheric pressure (+1 psi, $-0 \mathrm{psi})$.

4.4.20 Close He valve.

4.4.21 Record backfill pressure reading on Attachment 8 .

\section{SIGN-OFF}

4.4.22 Begin timing for 3-minute dwell time.

4.4.23 Monitor pressure gauge and add $\mathrm{He}$ as required to maintain $\mathrm{He}$ atmosphere in the cavity. 
NOTE

A dwell time of 3 minutes will be used to determine leakage rate of OCV upper main O-ring seal.

4.4.24 Record measured leakage rate (RT) after 3-minute dwell time on Attachment 8.

\section{SIGN-OFF}

\section{NOTE}

Steps 4.5.1 through 4.5.6 may be performed in parallel with Steps 4.4.25 through 4.4.33.

4.4.25 Remove test assembly from leak detector.

4.4.26 Install calibrated leak to leak detector.

4.4.27 Perform post-test calibration of leak detector and record results on Attachment 8.

\section{SIGN-OFF}

4.4.28 Calculate OCV main O-ring seal leakage rate by using the applicable condition below and record on Attachment 8.

\section{NOTE}

If background reading (RB) is larger than the leak rate reading (RT), then the background reading will not be subtracted from the leak rate reading and this (RT) becomes the actual leakage rate reading.

[A] If there is NO difference in the post-test calibration from the pretest calibration, use the following equation: subtract the $\mathrm{He}$ background at the start of test (RB) from the He background at end of test (RT). The leakage rate is (RT - RB) $x$ CCF. This equals the leakage rate for this segment of the test.

[B] If post-test calibration is LESS than pretest calibration, use the following calculation: (RT + calibration difference - RB) x CCF. This equals the leakage rate for this segment of the test under this condition of recalibration.

[C] If post-test calibration is MORE than pretest calibration, use the following calculation: (RT - calibration difference - RB) x CCF. This equals the leakage rate for this segment of the test under this condition of recalibration.

\section{SIGN-OFF}


4.4.29 If acceptance criterion is satisfied $\left(\leq 2.6 \times 10^{-7} \mathrm{scc} / \mathrm{s}\right.$ of $\left.\mathrm{He}\right)$, this segment of the test procedure is complete.

\section{NOTE}

Leakage rate acceptance criterion is $\leq 2.6 \times 10^{-7} \mathrm{scc} / \mathrm{s} \mathrm{He}$.

4.4.30 IF OCV main O-ring seal leakage rate is $>2.6 \times 10^{-7} \mathrm{scc} / \mathrm{s} \mathrm{He}$, THEN perform the following:

[A] Isolate leak path.

[B] GO TO WI-CH.02, replace O-ring seal(s) and/or repair seal surface(s) per WI-CH.12, and repeat leak test.

[C] If after repeated testing it is clear the seal cannot pass test, prepare NCR and record on Attachment 8.

\section{SIGN-OFF}

4.4.31 Remove OCV seal leak check tool and associated leak test equipment from OCV seal test port.

4.4.32 Install OCV seal test port plug.

4.4.33 Torque OCV seal test port plug to 55 to $65 \mathrm{lb}$-in and initial Attachment 8.

\section{SIGN-OFF}

\subsection{OCV Vent Port Plug O-Ring Seal}

\section{NOTE}

The following test should be performed immediately after Subsection 4.4, OCV Upper Main O-Ring Seal, while He atmosphere is still present in OCV cavity and to minimize He saturation of O-rings before test completion.

4.5.1 Disconnect vacuum pump assembly and He supply from OCV vent port tool.

4.5.2 Install OCV vent port plug.

4.5.3 Remove vent port tool.

4.5.4 Torque OCV vent port plug to 55 to $65 \mathrm{lb}$-in. and initial Attachment 8 .

\section{SIGN-OFF}

4.5.5 Purge vent port to flush out residual helium. 
4.5.6 Install a clean (helium-free) OCV leak detection tool in OCV vent port.

\section{NOTE}

If Step 4.5.7 begins within 1 hour of completing OCV upper main O-ring seal leak test, THEN pretest calibration is not required. Post-test calibration results can be used for the OCV outer vent port plug O-ring seal pretest calibration.

4.5.7 Perform pretest calibration of leak detector (to the temperaturecorrected standard leak value).

4.5.8 Record pretest calibration results on Attachment 8.

\section{SIGN-OFF}

4.5.9 Connect leak detector to OCV leak detection tool (see Figure 4.4, OCV Vent Port Plug O-Ring Seal Test).

4.5.10 Verify isolation valve is OPEN.

4.5.11 Evacuate OCV leak detection tool.

\section{NOTE}

To measure $\mathrm{a} \leq 2.6 \times 10^{-7} \mathrm{scc} / \mathrm{s}$ He leakage rate with a He atmosphere already present, indicated He background will be $\leq 2.6 \times 10^{-7} \mathrm{scc} / \mathrm{s}$ He before the start of the dwell time.

Dwell time for OCV vent port plug O-ring seal test is 3 minutes. An initial indication does NOT necessarily indicate a leak. Residual He may still be detected.

4.5.12 Record measured leakage rate (RT) after 3-minute dwell time on Attachment 8.

\section{SIGN-OFF}

4.5.13 Remove test assembly from leak detector.

4.5.14 Install calibrated leak to leak detector.

4.5.15 Perform post-test calibration of leak detector and record results on Attachment 8.

\section{SIGN-OFF}


4.5.16 Calculate OCV vent port plug O-ring seal leakage rate by using the applicable condition below and record on Attachment 8:

[A] If there is NO difference in the post-test calibration from the pretest calibration, the He background at end of test (RT) x CCF equals the leakage rate for this segment of the test.

[B] If post-test calibration is LESS than pretest calibration, use the following calculation: (RT + calibration difference) $x$ CCF. This equals the leakage rate for this segment of the test under this condition of recalibration.

[C] If post-test calibration is MORE than pretest calibration, use the following calculation: (RT - calibration difference) $x$ CCF. This equals the leakage rate for this segment of the test under this condition of recalibration.

\section{SIGN-OFF}

4.5.17 If acceptance criterion is satisfied $\left(\leq 2.6 \times 10^{-7} \mathrm{scc} / \mathrm{s}\right.$ of $\left.\mathrm{He}\right)$, this segment of the test procedure is complete.

NOTE

Leakage rate acceptance criterion is $\leq 2.6 \times 10^{-7} \mathrm{scc} / \mathrm{s} \mathrm{He}$.

4.5.18 IF OCV vent port plug O-ring seal leakage rate is $>2.6 \times 10^{-7} \mathrm{scc} / \mathrm{s} \mathrm{He}$,

THEN perform the following:

[A] Isolate leak path.

[B] GO TO WI-CH.01, replace O-ring seal(s) and/or repair seal surface(s) per WI-CH.12, and repeat leak test.

[C] If after repeated testing it is clear the seal cannot pass test, prepare an NCR and record on Attachment 8.

\section{SIGN-OFF}

4.5.19 Remove OCV leak detection tool from OCV vent port.

4.5.20 Install OCV vent port cover.

4.5.21 Torque OCV vent port cover to 55 to $65 \mathrm{lb}$-in. and initial Attachment 8.

\section{SIGN-OFF}

4.5.22 Install OCV seal test port thermal plug and access plug. 
4.5.23 Torque OCV seal test port access plug to 35 to $45 \mathrm{lb}$ - $\mathrm{ft}$ and initial Attachment 8.

\section{SIGN-OFF}

4.5.24 Install OCV vent port thermal plug and access plug.

4.5.25 Torque OCV vent port access plug to 35 to $45 \mathrm{lb}-\mathrm{ft}$ and initial Attachment 8.

\section{SIGN-OFF}

4.5.26 GO TO Step 2.19.16. 
Figure 4.1. ICV Main O-Ring Seal Test

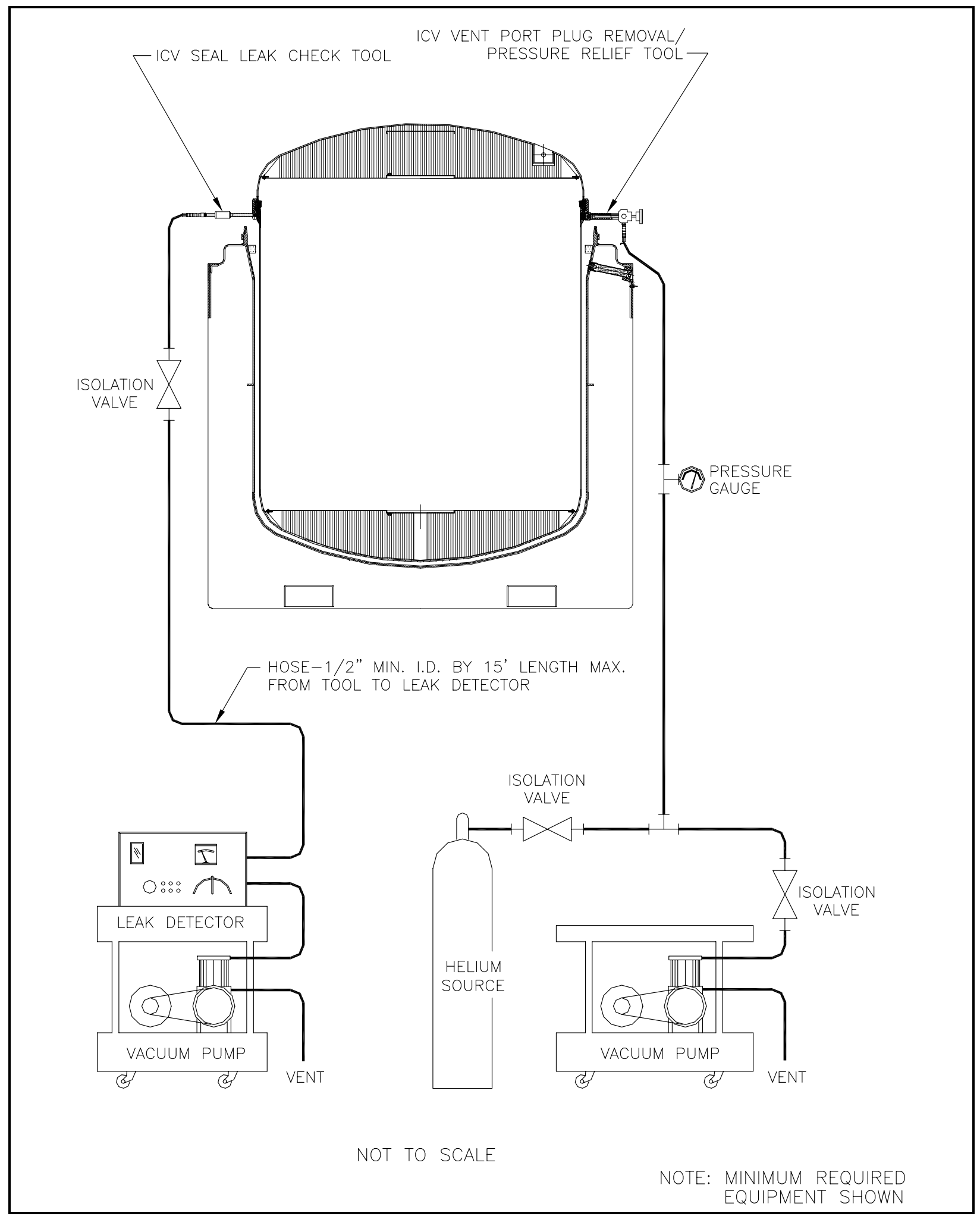


Rev. 1

Page 79 of 96

Figure 4.2. ICV Outer Vent Port Plug O-Ring Seal Test

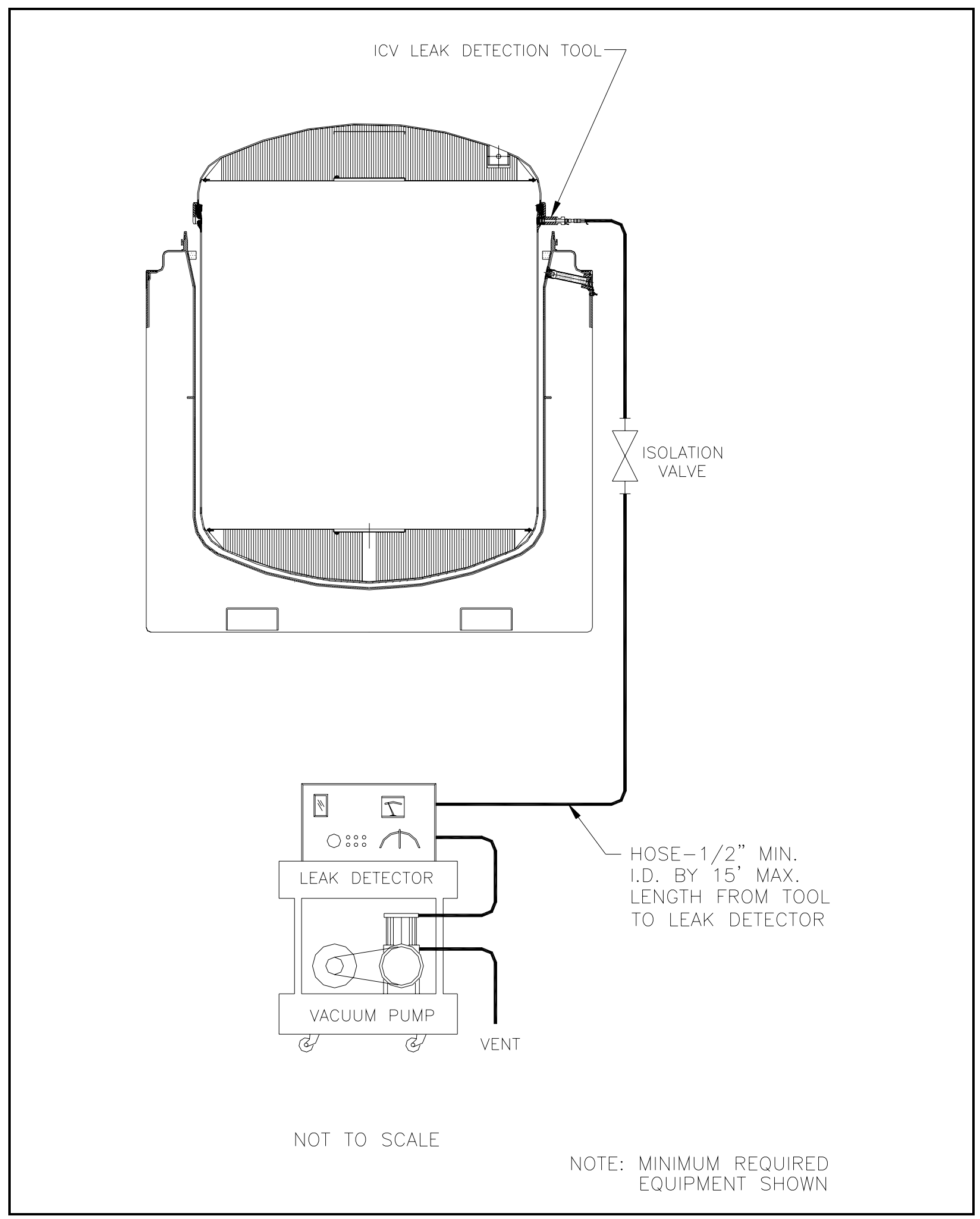


Figure 4.3. OCV Main O-Ring Seal Test

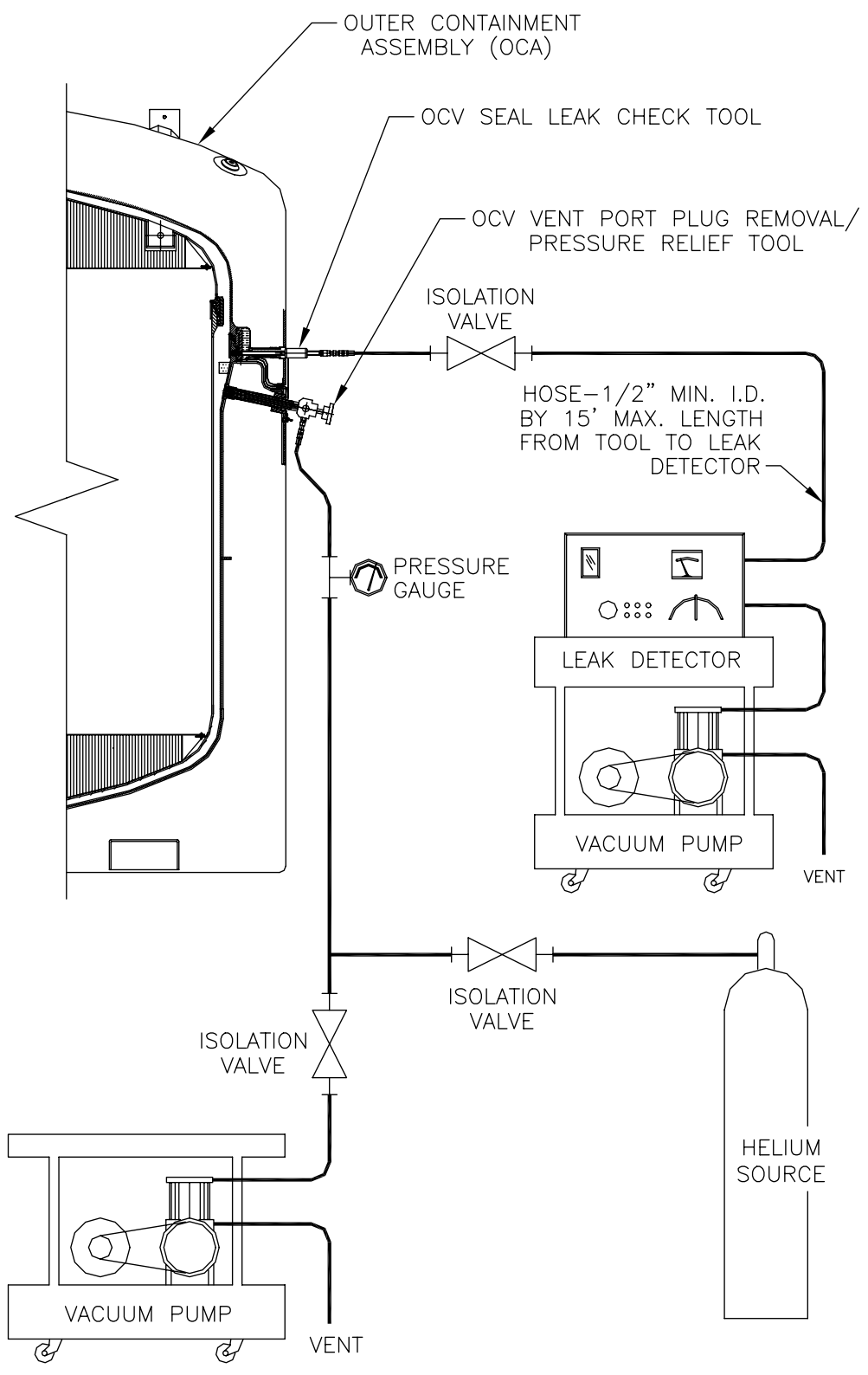

NOT TO SCALE 
Rev. 1

Page 81 of 96

Figure 4.4. OCV Vent Port Plug O-Ring Seal Test

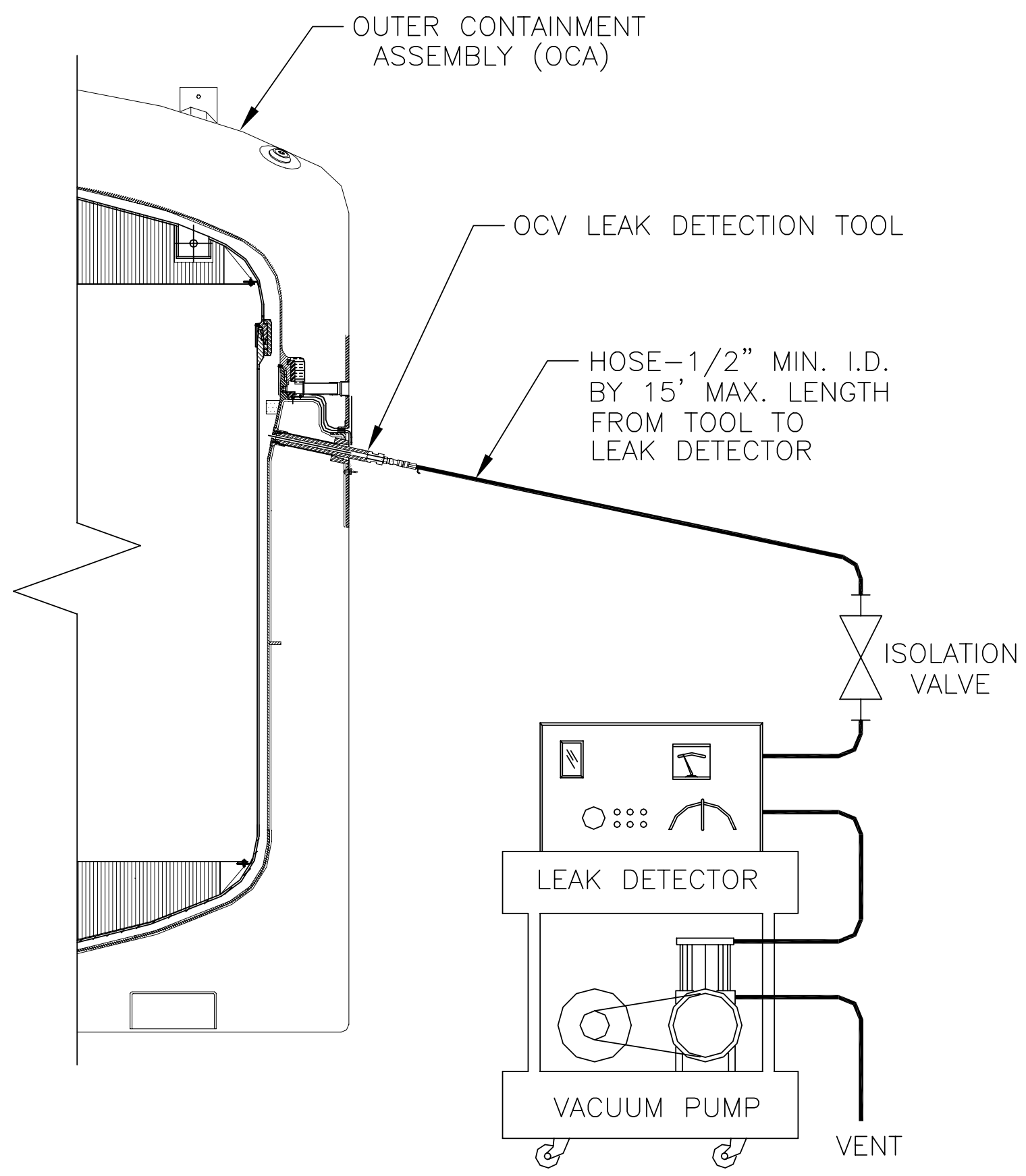

NOT TO SCALE

NOTE: 1. MINIMUM REQUIRED EQUIPMENT SHOWN 


\section{Attachment 1 - LANL High Wattage CH Packaging Receipt and Inspection Data Sheet}

\begin{tabular}{|c|c|c|}
\hline \multicolumn{3}{|c|}{ CH Packaging Receipt and Inspection Data Sheet } \\
\hline STEP(S) & DESCRIPTION & INITIALS \\
\hline Facility: & Date: & \\
\hline 2.2.1 & OCA serial number: & \\
\hline \multicolumn{3}{|c|}{ PERFORMANCE } \\
\hline 2.2.2 & $\begin{array}{l}\text { Shipping documents validated, packaging undamaged and released, and } \\
\text { nameplate checked }\end{array}$ & \\
\hline 2.2 .3 & Maintenance labels are present and maintenance is current & \\
\hline 2.7.1 & $\begin{array}{l}\text { Activity on smears is below DOT acceptable limits } \\
\text { Survey No: }\end{array}$ & \\
\hline 2.7 .4 & OCA lid components and hardware satisfactory & \\
\hline 2.8.1 & $\begin{array}{l}\text { Activity on smears is below DOT acceptable limits } \\
\text { Survey No: } \\
\text { Survey Date: }\end{array}$ & \\
\hline 2.8 .7 & ICV lid components and hardware satisfactory & \\
\hline 2.9 .1 & $\begin{array}{l}\text { Activity on smears is below DOT acceptable limits } \\
\text { Survey No: } \quad \text { Survey Date: }\end{array}$ & \\
\hline 2.9 .5 & OCA body inspection satisfactory & \\
\hline 2.10 .10 & OCA components and hardware satisfactory & \\
\hline 2.11 .4 & ICV body inspection satisfactory & \\
\hline 2.12 .9 & ICV components and hardware satisfactory & \\
\hline 2.13 .4 & ICV free of water & \\
\hline 2.14 & Pre-loading preparations and inspections complete & \\
\hline
\end{tabular}

Performers, enter printed name, signature, date and initials:

Printed Name

REMARKS:

REVIEW/VALIDATIONS:

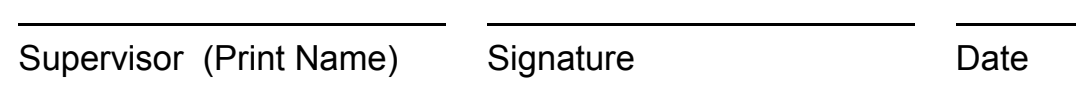




\section{Attachment 2 - LANL High Wattage CH Packaging Loading Data Sheet}

\begin{tabular}{|c|c|c|c|c|}
\hline \multicolumn{5}{|c|}{ CH Packaging Loading Data Sheet } \\
\hline STEP(S) & \multicolumn{3}{|l|}{ DESCRIPTION } & INITIALS \\
\hline Facility: & \multicolumn{2}{|l|}{ LANL } & Date: & \\
\hline 2.16 .1 & \multicolumn{3}{|l|}{ OCA serial number: } & \\
\hline \multicolumn{5}{|c|}{ PERFORMANCE } \\
\hline 2.16 .8 & \multicolumn{3}{|l|}{ Payload assembly weight: } & \\
\hline 2.16 .10 & \multicolumn{3}{|l|}{ Empty packaging weight: } & \\
\hline 2.16 .11 & \multicolumn{3}{|l|}{$\begin{array}{l}\text { Loaded package total weight: } \\
\text { Not to exceed } 19,250 \mathrm{lb}\end{array}$} & \\
\hline 2.17 .1 & \multicolumn{3}{|l|}{ ICV serial number: } & \\
\hline \multirow[t]{2}{*}{2.17 .2} & Torque wrench $\mathrm{S} / \mathrm{N}$ : & Due: & & \\
\hline & Torque wrench $\mathrm{S} / \mathrm{N}:$ & Due: & & \\
\hline 2.17 .11 & \multicolumn{3}{|l|}{ Ambient atmospheric pressure: } & \\
\hline 2.17 .21 & \multicolumn{3}{|l|}{ ICV pressure: } & \\
\hline 2.17 .23 & Time: & Date: & & \\
\hline 2.18 .14 & \multicolumn{3}{|l|}{ ICV inner vent port plug at specified value } & \\
\hline 2.18 .16 & \multicolumn{3}{|l|}{ ICV lock ring bolts at specified values } & \\
\hline 2.18 .17 & \multicolumn{3}{|l|}{ ICV preshipment leakage rate test performed } & \\
\hline 2.19 .1 & \multicolumn{3}{|l|}{ OCA lid and body serial numbers match } & \\
\hline 2.19 .14 & \multicolumn{3}{|l|}{ OCA lock ring bolts at specified values } & \\
\hline 2.19 .15 & \multicolumn{3}{|l|}{ OCV preshipment leakage rate test performed } & \\
\hline 2.19 .18 & \multicolumn{2}{|c|}{$\begin{array}{l}\text { Tamper indicating security seals installed and numbers recorded } \\
\text { Seal No: } \\
\text { Seal No: }\end{array}$} & & \\
\hline
\end{tabular}

Performers, enter printed name, signature, date and initials:

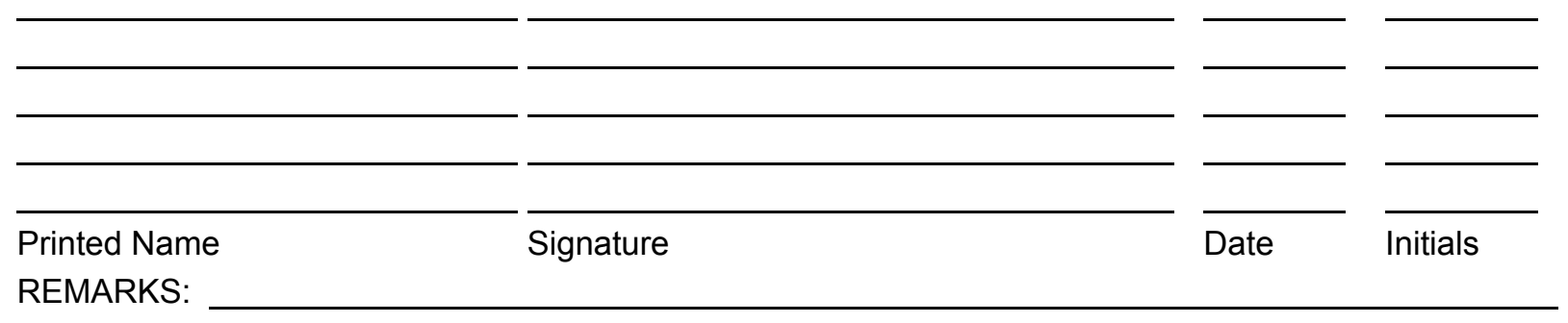

REVIEW/VALIDATIONS: 
Attachment 3 - LANL High Wattage Loaded CH Package Trailer Data Sheet

\begin{tabular}{|c|c|c|c|c|c|c|}
\hline \multicolumn{7}{|c|}{ Loaded CH Package Trailer Data Sheet } \\
\hline STEP(S) & \multicolumn{5}{|c|}{ DESCRIPTION } & Initials \\
\hline Facility: & \multicolumn{4}{|l|}{ LANL } & \multicolumn{2}{|l|}{ Date: } \\
\hline \multicolumn{7}{|c|}{ PERFORMANCE } \\
\hline \multirow{3}{*}{$\begin{array}{c}2.16 .2 \\
\text { or } \\
2.20 .1\end{array}$} & \multirow{3}{*}{\multicolumn{5}{|c|}{$\begin{array}{l}\text { Shipment No.: } \\
\text { Trailer No.: } \\
\text { Package Nos.: }\end{array}$}} & \\
\hline & & & & & & \\
\hline & & & & & & \\
\hline 2.20 .3 & \multicolumn{5}{|l|}{ Trailer Inspection Date: } & \\
\hline \multirow{3}{*}{2.20 .6} & Position \#1 package S/N: & & & & & \\
\hline & Position \#2 package S/N: & & & 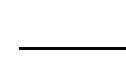 & $\mathrm{lb}$ & \\
\hline & Position \#3 package S/N: & & & 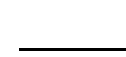 & & \\
\hline 2.20 .7 & \multicolumn{5}{|c|}{ Payload weight: } & \\
\hline 2.20 .8 & \multicolumn{5}{|c|}{ Shipment complies with 49 CFR Part 172, Subparts D, E, and F } & \\
\hline 2.20 .10 & \multicolumn{5}{|c|}{ Shipping papers comply with 49 CFR Part 172 , Subpart C } & \\
\hline 2.20 .11 & $\mathrm{~T}_{\text {ship }}$ & Time & & Date & & \\
\hline 2.20 .12 & $\mathrm{~T}_{\text {staging }}=$ & & & Hours & & \\
\hline 2.20 .13 & $\mathrm{~T}_{\text {staging }}<24$ hours & & & & & \\
\hline
\end{tabular}

Performers, enter printed name, signature, date and initials:

Printed Name

REMARKS:

REVIEW/VALIDATIONS: 
Attachment 4 - LANL High Wattage Loaded Package Receipt and Processing Data Sheet

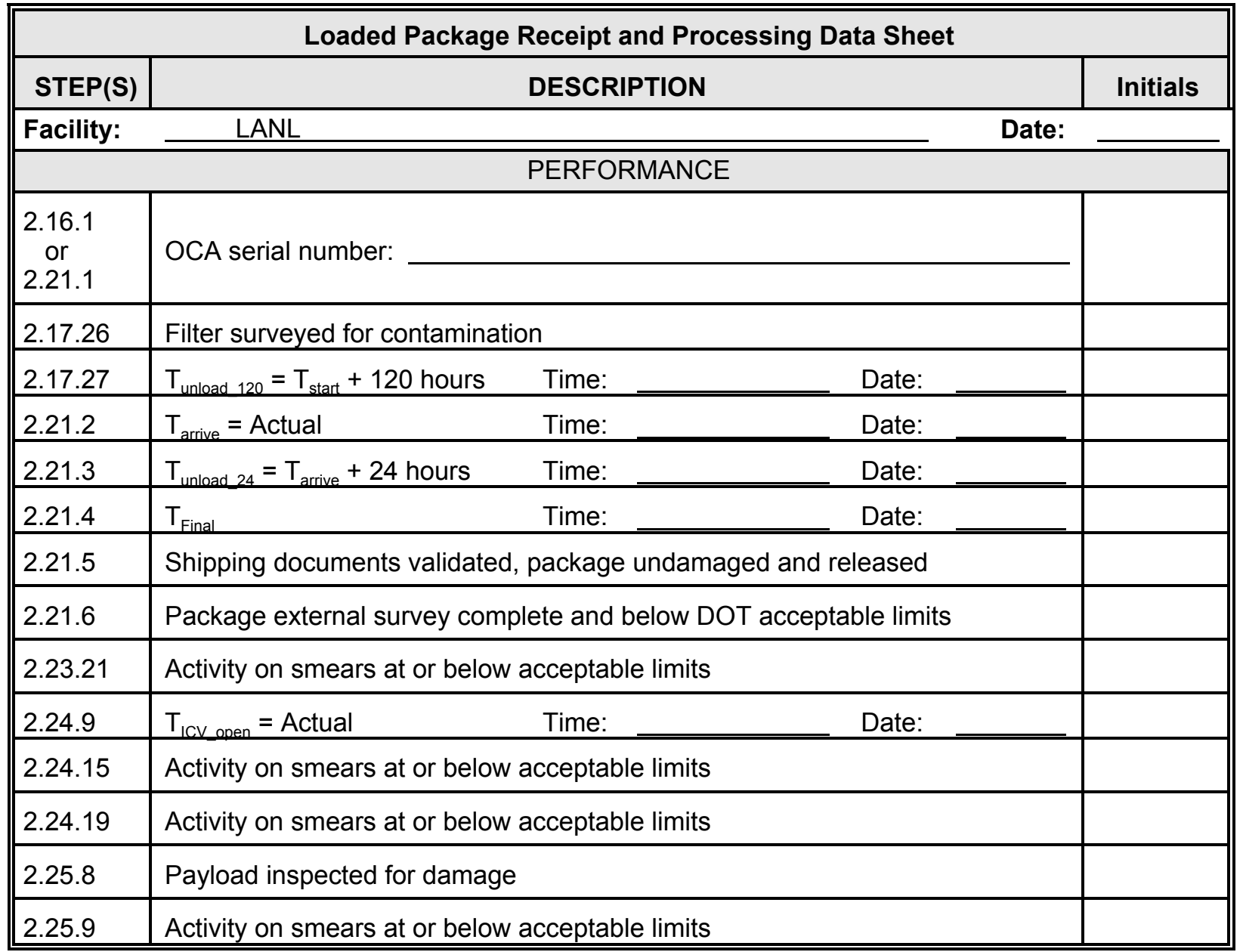

Performers, enter printed name, signature, date and initials:

Printed Name

REMARKS:

REVIEW/VALIDATIONS:

$$
\text { Supervisor (Print Name) }
$$




\section{Attachment 5 - LANL High Wattage Empty Packaging Shipment Data Sheet}

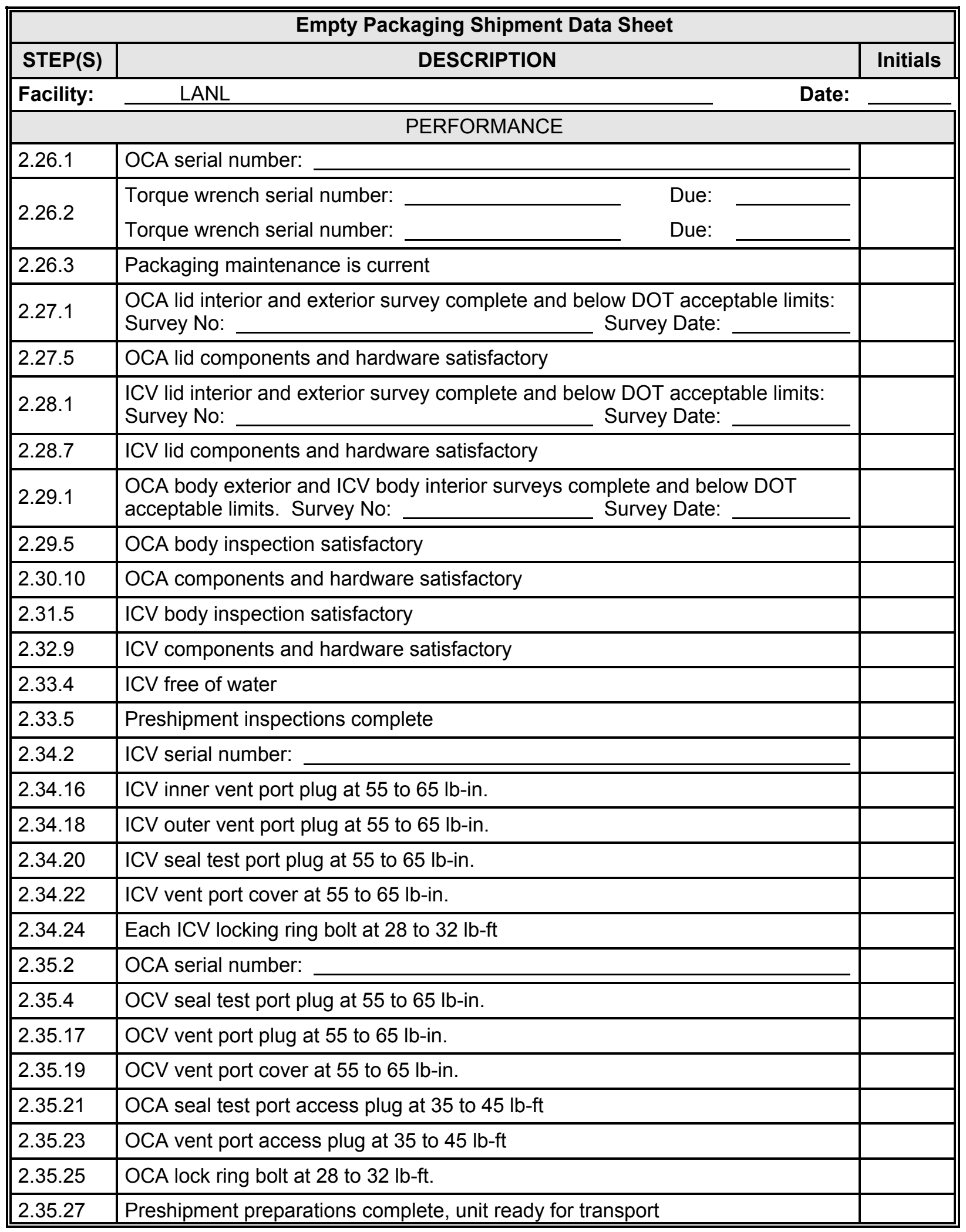


Attachment 5 - LANL High Wattage Empty Packaging Shipment Data Sheet

Performers, enter printed name, signature, date and initials:

Printed Name

REMARKS:

REVIEW/VALIDATIONS:

Supervisor (Print Name) 
Attachment 6 - LANL High Wattage Trailer Data Sheet

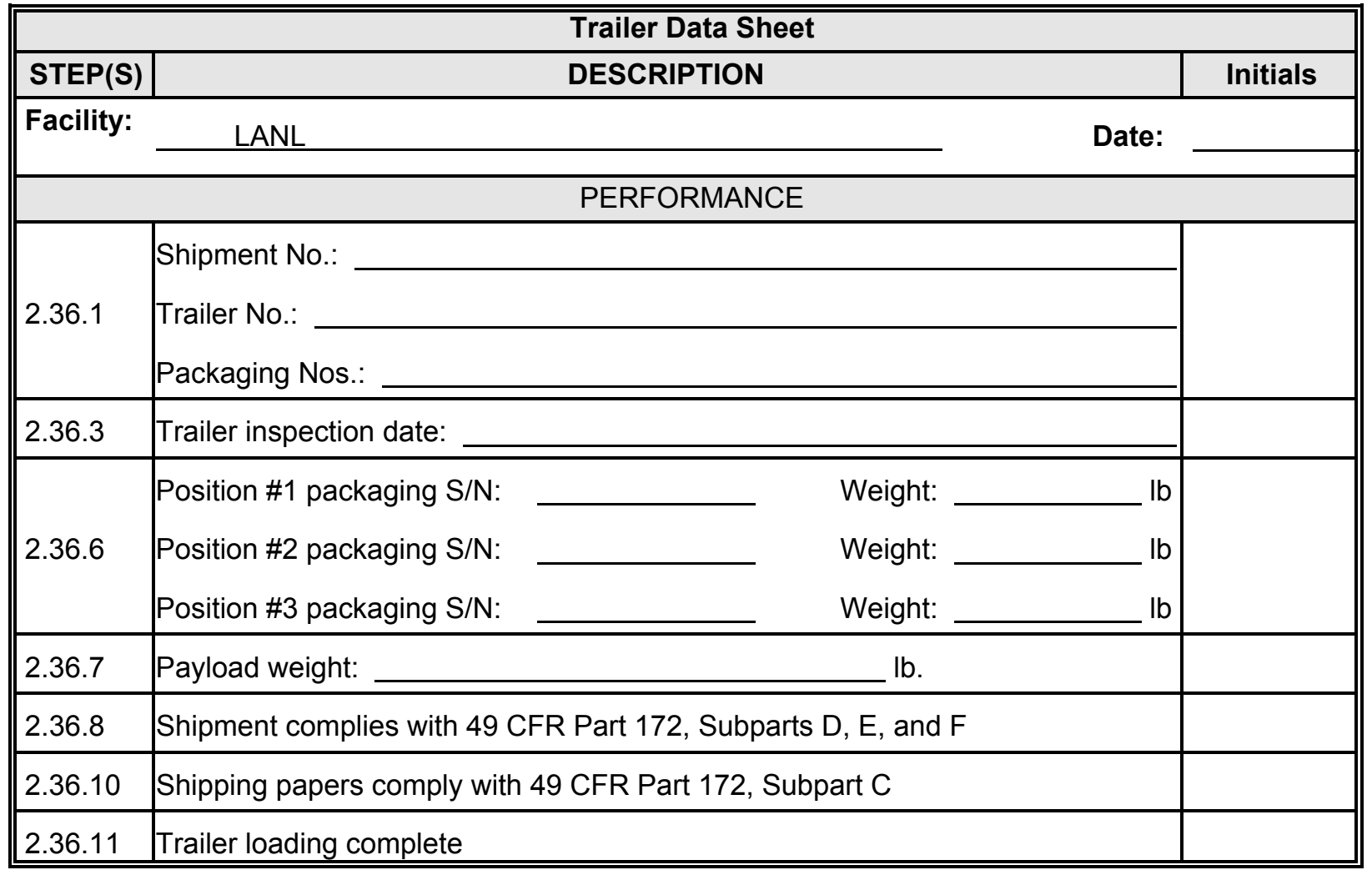

Performers, enter printed name, signature, date and initials:

Printed Name

REMARKS:

REVIEW/VALIDATIONS:

Supervisor (Print Name)

Signature

Date 


\section{Attachment 7 - ICV Preshipment Leakage-Rate Test Data Sheet}

\begin{tabular}{|c|c|c|c|}
\hline Step(s) & Basic Data & & \\
\hline \multirow[t]{9}{*}{4.2 .1} & ICV body S/N: & Date: & \\
\hline & MSLD model: & S/N: & \\
\hline & Vacuum/pressure gauge $\mathrm{S} / \mathrm{N}$ : & Due: & \\
\hline & Thermometer serial number: & Due: & \\
\hline & Torque wrench serial number: & Due: & \\
\hline & Torque wrench serial number: & Due: & \\
\hline & Calibrated leak serial number: & Due: & \\
\hline & Barometer serial number: & Due: & \\
\hline & Helium source connected & Initials: & \\
\hline \multirow[t]{2}{*}{4.2 .4} & ICV surface temperature: & & ${ }^{\circ} \mathrm{C}$ \\
\hline & Concentration Correction Factor Data & & \\
\hline \multirow{4}{*}{$\begin{array}{l}4.2 .10 \\
4.2 .12 \\
4.2 .14 \\
\end{array}$} & Ambient atmospheric pressure: & & in. $\mathrm{Hg}$ (Patm) \\
\hline & Vacuum reading: & & in. $\mathrm{Hg}(\mathrm{V} 1)$ \\
\hline & Concentration Correction Factor $(\mathrm{CCF})=$ Patm/V1: & & \\
\hline & Pretest Calibration for ICV Main O-Ring Seal Test & & \\
\hline \multirow[t]{6}{*}{4.2 .15} & Leak rate of standard leak: & & $\mathrm{scc} / \mathrm{s}$ \\
\hline & Temperature at time of calibration: & & ${ }^{\circ} \mathrm{C}$ \\
\hline & $\begin{array}{l}\text { Temperature adjusted leak rate used to calibrate leak } \\
\text { detector: }\end{array}$ & & $\mathrm{scc} / \mathrm{s}$ \\
\hline & Zero reading at time of calibration: & & $\mathrm{scc} / \mathrm{s}$ \\
\hline & Time of calibration: & & \\
\hline & Test Data for ICV Main O-Ring Seal & & \\
\hline \multirow{4}{*}{$\begin{array}{l}4.2 .20 \\
4.2 .23 \\
4.2 .26 \\
\end{array}$} & He background (RB): & & $\mathrm{scc} / \mathrm{s}$ \\
\hline & Pressure reading at end of $\mathrm{He}$ backfill: & & psi \\
\hline & He reading after $\quad 3 \quad$ minute dwell $(R T)=$ & & $\mathrm{scc} / \mathrm{s}$ \\
\hline & Post-test Calibration for ICV Main O-Ring Seal Test & & \\
\hline \multirow[t]{4}{*}{4.2 .29} & Temperature at time of recalibration: & & ${ }^{\circ} \mathrm{C}$ \\
\hline & He reading with standard leak installed: & & $\mathrm{scc} / \mathrm{s}$ \\
\hline & Zero reading at time of calibration: & & $\mathrm{scc} / \mathrm{s}$ \\
\hline & Time of calibration: & & \\
\hline
\end{tabular}




\section{Attachment 7 - ICV Preshipment Leakage-Rate Test Data Sheet}

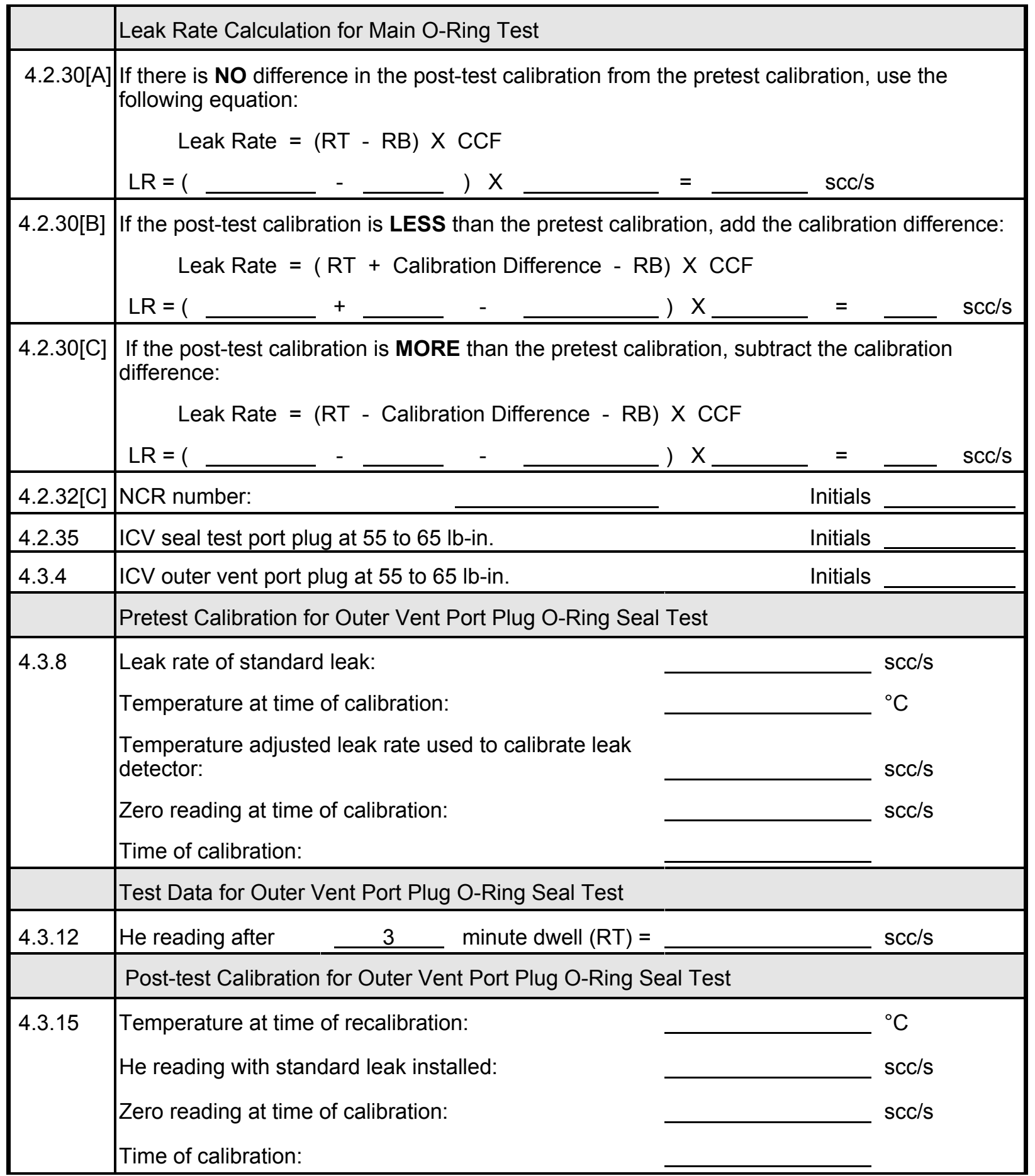




\section{Attachment 7 - ICV Preshipment Leakage-Rate Test Data Sheet}

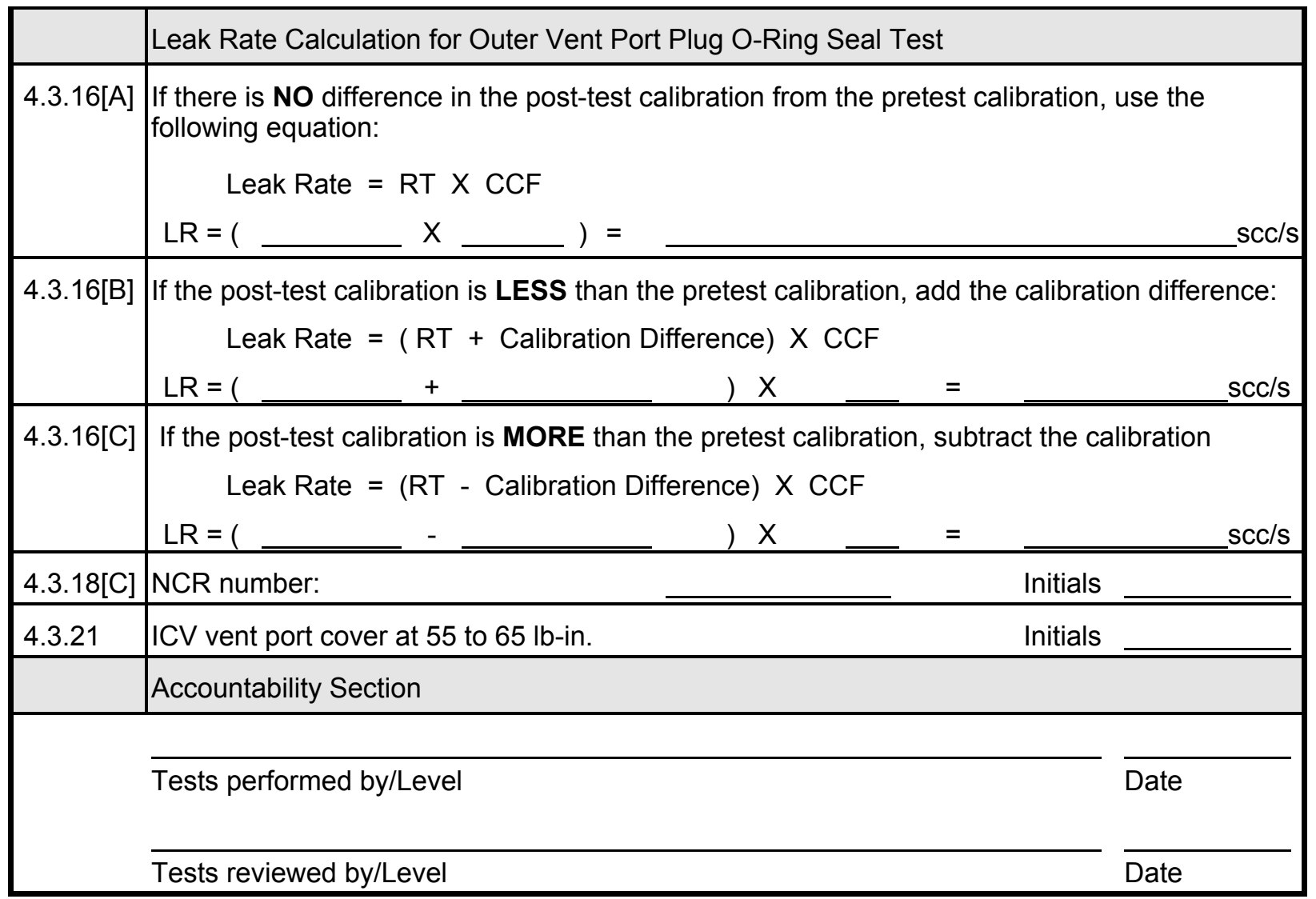




\section{Attachment 8 - OCV Preshipment Leakage-Rate Test Data Sheet}

\begin{tabular}{|c|c|c|}
\hline Step(s) & Basic Data & \\
\hline \multirow[t]{9}{*}{ 4.4.1 } & OCV body S/N: _ & Date: \\
\hline & MSLD model: & $\mathrm{S} / \mathrm{N}:$ \\
\hline & Pressure/vacuum gauge $\mathrm{S} / \mathrm{N}$ : & Due: \\
\hline & Thermometer serial number: & Due: \\
\hline & Torque wrench serial number: & Due: \\
\hline & Torque wrench serial number: & Due: \\
\hline & Standard leak serial number: & Due: \\
\hline & Barometer serial number: & Due: \\
\hline & Helium source connected & Initials: \\
\hline \multirow[t]{2}{*}{ 4.4.2 } & OCV surface temperature: & ${ }^{\circ} \mathrm{C}$ \\
\hline & Concentration Correction Factor Data & \\
\hline \multirow{4}{*}{$\begin{array}{l}4.4 .7 \\
4.4 .9 \\
4.4 .11 \\
\end{array}$} & Ambient atmospheric pressure: & in. $\mathrm{Hg}($ Patm) \\
\hline & Vacuum reading: & in. $\mathrm{Hg}(\mathrm{V} 1)$ \\
\hline & Concentration Correction Factor $(\mathrm{CCF})=$ Patm $/ \mathrm{V} 1$ : & \\
\hline & Pretest Calibration for OCV Main O-Ring Seal Test & \\
\hline \multirow[t]{6}{*}{4.4 .13} & Leak rate of standard leak: & scc/s \\
\hline & Temperature at time of calibration: & ${ }^{\circ} \mathrm{C}$ \\
\hline & $\begin{array}{l}\text { Temperature adjusted leak rate used to calibrate leak } \\
\text { detector: }\end{array}$ & scc/s \\
\hline & Zero reading at time of calibration: & scc/s \\
\hline & Time of calibration: & \\
\hline & Test Data for OCV Main O-Ring Seal & \\
\hline \multirow{4}{*}{$\begin{array}{l}4.4 .18 \\
4.4 .21 \\
4.4 .24 \\
\end{array}$} & He background (RB): & scc/s \\
\hline & Backfill pressure reading at end of He backfill: & _ps \\
\hline & He reading after $\quad 3 \quad$ minute dwell $(R T)=$ & scc/s \\
\hline & Post-test Calibration for OCV Main O-Ring Seal Test & \\
\hline \multirow[t]{4}{*}{ 4.4.27 } & Temperature at time of recalibration: & ${ }^{\circ} \mathrm{C}$ \\
\hline & He reading with standard leak installed: & scc/s \\
\hline & Zero reading at time of calibration: & - scc/s \\
\hline & Time of calibration: & \\
\hline
\end{tabular}




\section{Attachment 8 - OCV Preshipment Leakage-Rate Test Data Sheet}

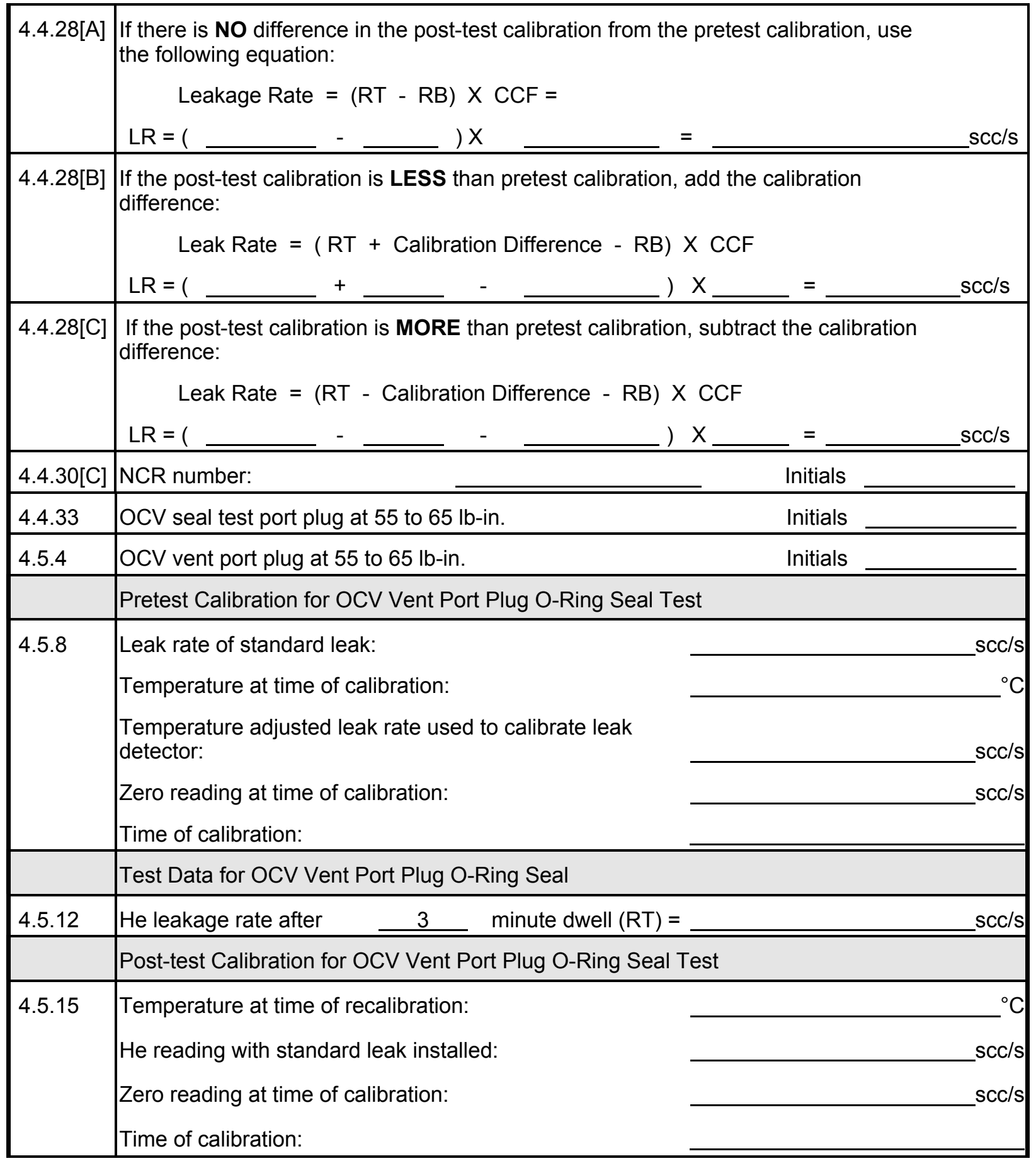




\section{Attachment 8 - OCV Preshipment Leakage-Rate Test Data Sheet}

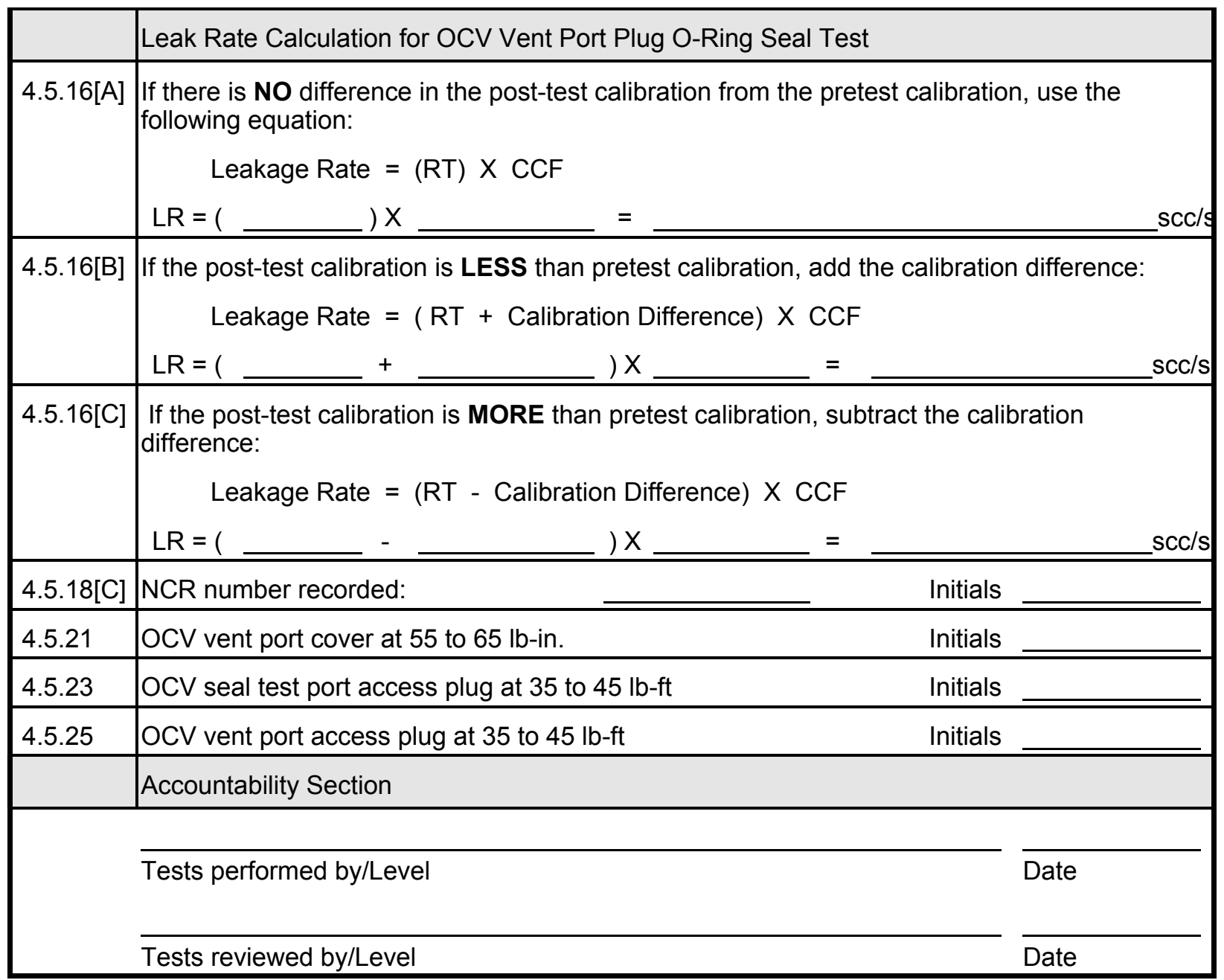




\section{Attachment 9 - Time and Date Data Sheet for Shipment of Content Code LA 154}

\begin{tabular}{|c|c|c|c|c|}
\hline \multicolumn{2}{|c|}{ Shipment No.: } & \multicolumn{2}{|c|}{ Packaging OCA Body/Lid No.: } & \\
\hline \multicolumn{5}{|c|}{ To be completed by LANL TCO or designee for each TRUPACT-II shipping content code LA- 154 . } \\
\hline Step No. & Activity & Date Recorded & Time Recorded & $\begin{array}{l}\text { Completion of } \\
\text { Activity (Indicate by } \\
\text { check mark }[\boldsymbol{V}] \text { ) }\end{array}$ \\
\hline 2.17.23 & $\mathrm{T}_{\text {start }}$ & & & \\
\hline 2.20 .11 & $\begin{array}{l}\text { Record date and time of } \\
\text { departure of shipment from } \\
\text { LANL }\end{array}$ & & & \\
\hline 2.20 .12 & $\begin{array}{l}\text { Calculate and record total } \\
\text { staging time } \\
\text { (Limit = } 24 \text { hours) }\end{array}$ & & $\mathrm{T}_{\text {staging }}={ }_{\mathrm{hrs}}$ & \\
\hline 2.20 .13 & $\mathrm{~T}_{\text {staging }}<24$ hours & & $=\ldots \mathrm{hrs}$ & \\
\hline \multicolumn{5}{|c|}{$\begin{array}{l}\text { I certify that the above data are accurate and compliant with the staging time limit of } 24 \text { hours, as } \\
\text { specified in this document and Appendix } 1.2 \text { of the TRAMPAC. }\end{array}$} \\
\hline \multicolumn{4}{|c|}{ Transportation Certification Official or Designee } & Date \\
\hline
\end{tabular}


Attachment 10 - Time and Date Data Sheet for Receipt of Content Code LA-154

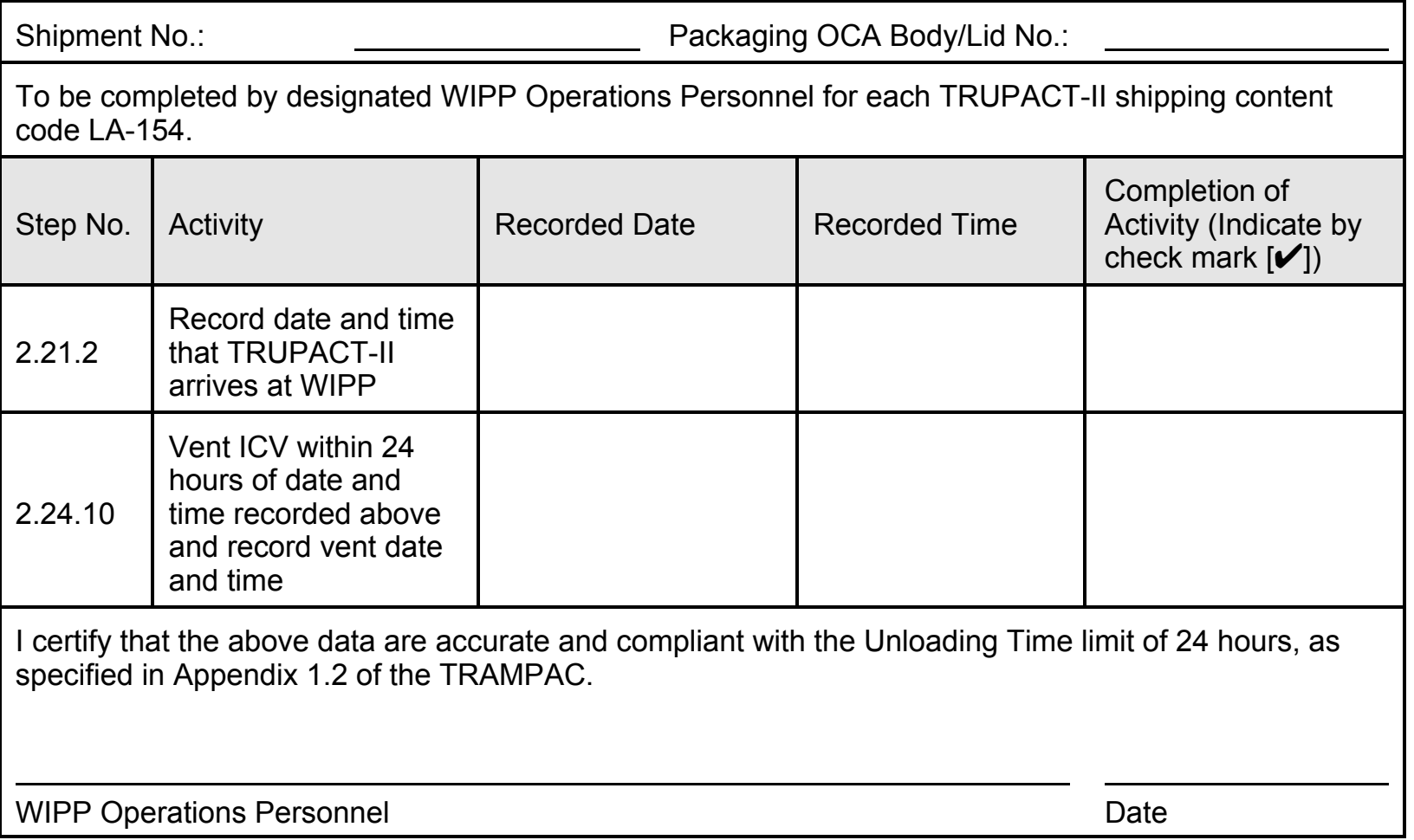

